\title{
Thermal functioning of a tropical reservoir assessed through three-dimensional modelling and high-frequency monitoring
}

\section{Comportamento térmico em um lago tropical urbano avaliado por modelagem tridimensional e monitoramento em alta frequência}

\author{
Denis Furstenau Plec ${ }^{1,2}$ (D), Talita Fernanda das Graças Silva ${ }^{1}$ (D), Brigitte Vinçon-Leite ${ }^{2}$ (D) \& Nilo Nascimento ${ }^{1}$ \\ ${ }^{1}$ Universidade Federal de Minas Gerais, Belo Horizonte, MG, Brasil \\ ${ }^{2}$ École des Ponts, Université Paris Est Créteil, Marne-la-Vallée, France \\ E-mails: denisfp@ufmg.br(DFP), talita.silva@ehr.ufmg.br (TFGS), b.vincon-leite@enpc.fr (BVL), niloon@ehr.ufmg.br (NN)
}

Received: October 14, 2020 - Revised: March 30, 2021 - Accepted: May 03, 2021

\begin{abstract}
Urban lakes and reservoirs provide important ecosystem services. However, their water quality is being affected by anthropogenic pressures. The thermal regime is a strong driver of the vertical transport of nutrients, phytoplankton and oxygen. Thermal stratification can modify biogeochemical processes. In this paper, a three-dimensional hydrodynamic model was implemented and validated with high-frequency measurement of water temperature. The simulation results were in agreement with the measurements. For all simulation period, the model performance was evaluated based on hourly values, presenting a maximum RMSE of $0.65{ }^{\circ} \mathrm{C}$ and Relative Error of $2.08 \%$. The results show that high-frequency measurement associated with a three-dimensional model could help to understand and identify the reasons for the changes in the thermal condition of a shallow urban lake. The impact of the stream inflow on the temperature was highlighted, showing that during higher discharge events, when the river temperature is colder than the lake water, it flows into the lake deeper layers. The inflow water sank to the deeper layers where the lake morphology changes. The model showed an impact along the entire lake, showing the importance of monitoring the inflow water temperature. This modelling tool could be further used to study specific patterns of reservoir hydrodynamics.
\end{abstract}

Keywords: Reservoir hydrodynamics; Thermal regime; Lake Pampulha, 3D hydrodynamic model.

\section{RESUMO}

Lagos e reservatórios urbanos fornecem importantes serviços ecossistêmicos. Porém, a qualidade da água está sendo afetada por diversas pressões antrópicas. O regime térmico é de particular importância no transporte vertical de nutrientes, fitoplâncton e oxigênio. A estratificação térmica dos reservatórios pode modificar processos biogeoquímicos. Nesse artigo, um modelo hidrodinâmico tridimensional foi implementado e validado com medição de temperatura da água em alta frequência. Os resultados das simulações ficaram de acordo com os dados medidos. Para todos os períodos simulados, o desempenho do modelo foi avaliado com base em valores horários, apresentando raiz quadrada do erro quadrático médio de $0,65^{\circ} \mathrm{C}$ e erro relativo de $2,08 \%$. Os resultados mostram que as medições de alta frequência associada ao modelo tridimensional ajudaram a compreender e identificar as causas das alterações na condição térmica de um lago urbano raso. O impacto de uma vazão afluente na temperatura do reservatório foi evidenciado, mostrando que durante eventos de grandes vazões, quando a temperatura do rio é mais fria que a temperatura do lago, ocorre o escoamento desta vazão pelas camadas mais profundas. A vazão afluente mergulha para camadas mais profundas onde a morfologia do lago se altera. O modelo mostrou um impacto por todo o lago, mostrando assim a importância de monitorar a temperatura da água afluente. Essa ferramenta numérica poderá ser futuramente utilizada para estudos sobre padrões específicos hidrodinâmicos do reservatório.

Palavras-chaves: Hidrodinâmica de reservatórios, regime térmico, Lagoa da Pampulha, modelo hidrodinâmico tridimensional. 


\section{INTRODUCTION}

In urban areas, lakes and reservoirs provide many ecosystem services. Environmental changes at a local scale, within their watersheds, and at a global scale are affecting the water quality and ecological functioning of urban lakes (Birch \& McCaskie, 1999; Friese et al., 2010; Li-Kun et al., 2017), resulting in an increase in phytoplankton biomass and the occurrence of potentially toxic cyanobacteria blooms (Davidson et al., 2016; Ho \& Michalak, 2015; Jöhnk et al., 2008; Whyte et al., 2014).

In lake ecosystems thermal stratification and a longer residence time of the water can boost the phytoplankton production (Jöhnk et al., 2008). Thermal stratification is of particular significance in regulating the vertical transport of nutrients, phytoplankton, and oxygen (Boegman et al., 2003; Gonçalves et al., 2016; Grimaud et al., 2017; Simpson et al., 2015). Water temperature impacts phytoplankton succession and community composition (Elliott, 2012; Grimaud et al., 2017; Jöhnk et al., 2008; Phlips et al., 2002; Reynolds, 1998; Van Donk, 1984; Vinçon-Leite \& Casenave, 2019). Wu et al. (2013) highlighted the need to investigate the influence of short-term hydrodynamics on cyanobacteria in shallow lakes, as the complex cyanobacteria motion in natural water bodies is poorly understood. Thus, understanding hydrodynamics and its interference on water quality bears great importance and needs to be investigated (Li-Kun et al., 2017; Qin et al., 2015; Wu et al., 2015; Zbiciński \& Ziemińska-Stolarska, 2017).

Most urban lakes are medium-size and shallow (Birch \& McCaskie, 1999; Gong et al., 2016). They may react strongly and rapidly to external hydrological and meteorological forcing, presenting many alternation periods of thermal stratification and mixing. Thus, high-frequency measurements are necessary to capture transient changes and to help understanding the relationship between factors that may impact ecological status. However, high-frequency monitoring is rarely used, especially in urban lakes in tropical regions.

Due to the complex interplay between ecological and hydrodynamic processes in lakes, with high heterogeneity in space and time, three-dimensional models help in better understanding the processes involved (Gong et al., 2016; Soulignac et al., 2017, 2018; Zbiciński \& Ziemińska-Stolarska, 2017). Usually in hydrodynamic three-dimensional models, hydrodynamic processes are represented in a sub-model that provides water temperature and velocity in time and space to an ecological sub-model. Three-dimensional models are increasingly implemented to better understand the lake ecosystem response to external pressures, like climate forcing, nutrient loading, and pollutant input (Aparicio Medrano et al., 2013; Chanudet et al., 2012; Soulignac et al., 2018; Vinçon-Leite \& Casenave, 2019; Yi et al., 2016). However, the use of three-dimensional modelling in urban lakes is much less reported (Soulignac et al., 2017), especially in tropical water bodies which are subjected to distinct conditions of external forcing and may present different responses compared to temperate water bodies. Furthermore, the use of high-frequency measurements in three-dimensional modelling studies in urban lakes is rarely found. Chanudet et al. (2012) used a three-dimensional model with high-frequency water temperature measurements in the shallow Nam Theun 2 Reservoir (Laos). However, the authors obtained high errors between simulated and measurement values in the reservoir deepest layer, especially during strong thermal stratification events. Soulignac et al. (2017) used three-dimensional model with high-frequency water temperature measurements in the shallow Lake Créteil (France). The authors could well represent the water temperature dynamics over all depths. Jin et al. (2000) used three-dimensional model with high-frequency water temperature measurements in the shallow Lake Okeechobee (USA). The authors obtained a considerable root mean square error of water temperature of $9.18 \%$. Jin et al. (2000) highlighted the wind-induced wave and sediment deposition/resuspension. However, none of them highlighted the impact of the inflow water temperature. Belico (2017) used a unidimensional model in the lake Pampulha (study site of the present article). The one-dimensional model could not rightly simulate the temperature in the deeper layers of the lake. Other modelling studies were previously applied to Lake Pampulha (Silva, 2014; Silva et al., 2016, 2019) however, none of them used three-dimensional modelling with high-frequency measurement in different depths.

This paper presents a rare application of three-dimensional modelling and water temperature high-frequency measurements in a shallow and medium-size tropical urban lake using hourly meteorological and inflow data. The main objective of this study is to associate high frequency measurements and three-dimensional hydrodynamic modelling in order to investigate the influence, during thermal stratification periods, of inflow water discharge and temperature and lake morphology on the lake thermal behaviour.

\section{MATERIALS AND METHODS}

\section{Study site}

Lake Pampulha is a reservoir located in Belo Horizonte, a city with 2.5 million inhabitants (Instituto Brasileiro de Geografia e Estatística, 2014) in the southeast of Brazil. Lake Pampulha and its modern urban ensemble, was designed by the architect Oscar Niemeyer and built in the 1940s. The climate characteristics of the lake region are of tropical altitude type (Companhia de Pesquisa de Recursos Minerais, 2001) and summarized in Table 1. Dry season occurs from April to September. Annual mean inflow in Lake Pampulha is $1.30 \mathrm{~m}^{3} / \mathrm{s}$ and 2-years return period inflow is $106.7 \mathrm{~m}^{3} / \mathrm{s}$ (Campos, 2004, Table 2).

Table 1. Lake Pampulha climate characteristics measured between 1961 and 2001 at Belo Horizonte's INMET meteorological station.

\begin{tabular}{cc}
\hline Climate & Tropical altitude \\
\hline Air temperature & Monthly maximum of $28.8^{\circ} \mathrm{C}$ (February) \\
& Monthly minimum of $13.1^{\circ} \mathrm{C}$ (July) \\
Dry season & April to September (monthly minimum $14 \mathrm{~mm}$ ) \\
Rainfall season & October to March (monthly maximum $320 \mathrm{~mm}$ )
\end{tabular}

Source: (Companhia de Pesquisa de Recursos Minerais, 2001).

Table 2. Lake Pampulha discharge frequenccy.

\begin{tabular}{cc}
\hline Return Period & Discharge $\left(\mathrm{m}^{3} / \mathbf{s}\right)$ \\
\hline Annual mean flow & 1.30 \\
2 years & 106.7 \\
10 years & 172.0 \\
50 years & 234.0 \\
100 year & 261.0 \\
\hline
\end{tabular}

Source: (Campos, 2004). 
Located at an altitude of $801 \mathrm{~m}$, Lake Pampulha has a surface area of approximately $2.0 \mathrm{~km}^{2}$ and a volume of about 10 million $\mathrm{m}^{3}$ at $801 \mathrm{~m}$ (spillway crest) with a residence time of 89 days (considering the annual mean inflow). The lake is a shallow reservoir with a maximum depth of $16 \mathrm{~m}$ and an average depth of $5 \mathrm{~m}$. The lake has a polymictic thermal regime, in which the thermal stratification of the water column during a few days alternates with mixing episodes. Lake Pampulha catchment, composed of 8 main tributaries, has a surface area of about $98 \mathrm{~km}^{2}$ (Companhia de Pesquisa de Recursos Minerais, 2001), with more than 70\% urbanised (Matos et al., 2017) and approximately 500,000 inhabitants. Lake Pampulha was built for many purposes, including drinking water supply. However, due to an intense urbanisation process in the lake catchment from the 1970 s on, the lake water quality was severely compromised resulting in a hypereutrophic reservoir, leading to the interruption of drinking water provision from the 1980s, with frequent cyanobacteria blooms (Silva, 2014) and presenting a hypoxia condition at the bottom of the lake (Friese et al., 2010; von Sperling \& Campos, 2011).

In 2016, the lake has become a UNESCO World Heritage site, which boosted public sector to seek for water quality improvement actions. The municipality of Belo Horizonte (PBH) committed to invest about $\mathrm{R} \$ 30$ million to recover the water quality of Lake Pampulha over 12 months, starting from March 2016 (Prefeitura de Belo Horizonte, 2016). Phoslock ${ }^{\circledR}$ and Enzilimp ${ }^{\circledR}$ were applied in the lake in order to remove phosphorus from the water column and to reduce coliforms and the Biochemical Oxygen Demand - BOD (Barçante et al., 2020). The treatment was renewed for another year at the cost of about R \$ 16 million. Efforts to improve sanitation infrastructure in the Pampulha catchment were also carried out aiming at collecting $95 \%$ of sewage at an investment of $\mathrm{R} \$ 875$ million from 2004 to 2016 (Prefeitura de Belo Horizonte, 2017).

\section{Available data}

Concerning the lake water inflow, since 2011 monitoring stations integrate a Hydrological Monitoring System (Figure 1) operated by PBH (Siqueira et al., 2019). Monitoring stations are present only on the two main tributaries, Sarandi stream (station SAR18F, $2.8 \mathrm{~km}$ upstream the lake), located at $19^{\circ} 52^{\prime}$ 01' south and $44^{\circ} 0$ ' 33" west and Ressaca stream (station RES17F, 2,0 km upstream the lake), located at $19^{\circ} 52^{\prime} 11^{\prime \prime}$ ' south and $43^{\circ} 59^{\prime}$ '57' west. These streams represent $70 \%$ of the reservoir inflow (Companhia de Pesquisa de Recursos Minerais, 2001). These stations measure water level. Nogueira (2015) determined the rating curves, i.e. the water level $\mathrm{x}$ discharge relationship, for both streams at the monitoring stations. In this study, the rating curves were used to obtain the inflow data from water level measurements during the simulation period. The other tributaries are not monitored. Thus, time series of the inflow discharges were estimated by multiplying

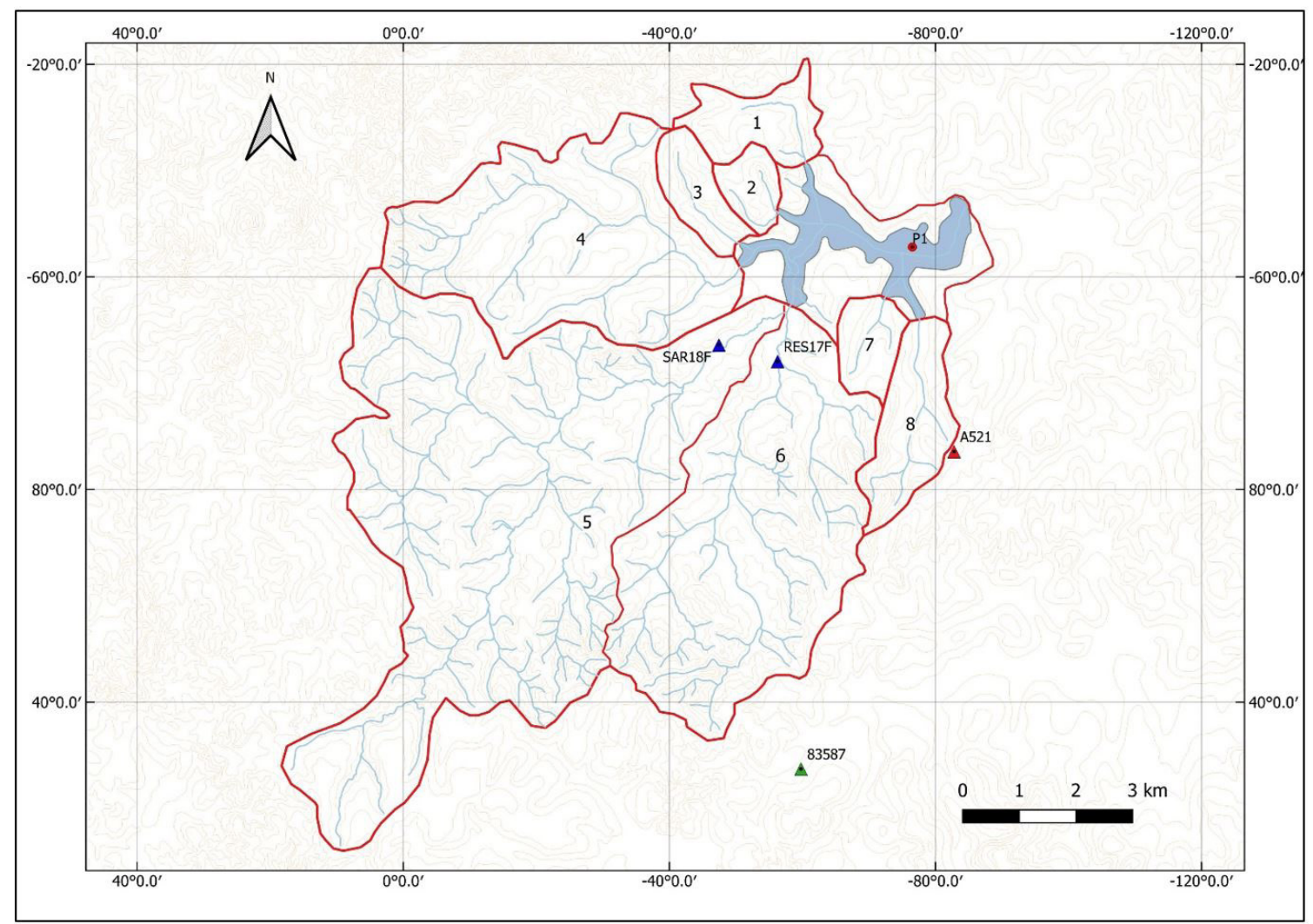

Figure 1. Location of Lake Pampulha and its tributaries: (1) Olhos d’água; (2) AABB*; (3) Bráunas; (4) Água Funda; (5) Sarandi; (6) Ressaca; (7) Tijuco and (8) Mergulhão. *river not named, popularly known as AABB (Associação Atlética Banco do Brasil- Athletics Association from Brazil Bank). Red lines indicate the respective catchment of the tributaries. Monitoring station in triangle: (1) Fluviometric (SAR18F - Sarandi and RES17F - Ressaca; (2) Meteorological station (A521 -UFMG and 83587 - Belo Horizonte);

(3) Lake monitoring (P1, red dot). 
the inflow time series of the reference stations by the ratio of each tributary catchment area divided by the catchment area of the reference stations.

Inflow water temperature was monitored for a short period of two months (April and May 2013) downstream the confluence of Ressaca and Sarandi streams (Silva et al., 2016). In this research we used hourly water inflow temperature. Two methods to estimate hourly water inflow temperature were evaluated. The first one was a linear regression with air temperature, used in previous studies (Chen \& Fang, 2015; Hébert et al., 2015; Stefan \& Preud'homme, 1993). The second method was the Modified Sine and Sinusoidal Wave Functions Model (MSSWF), proposed by Chen \& Fang (2016).

Hourly meteorological data (air temperature, air humidity, wind intensity and direction, and cumulative hourly solar radiation and precipitation) were provided by the National Institute of Meteorology of Brazil (INMET) and used as uniform values in the computation domain. The nearest automatic weather station (a521) is located inside the campus of the Universidade Federal de Minas Gerais at $19^{\circ} 53^{\prime} 02^{\prime \prime}$ south and $43^{\circ} 58^{\prime} 10^{\prime \prime}$ west, about $3 \mathrm{~km}$ from Lake Pampulha (Figure 1). The cloud coverage data are recorded at the meteorological station named Belo Horizonte (83587), located at $19^{\circ} 56^{\prime} 04^{\prime \prime}$ south and 43 59' 43' west, $9.5 \mathrm{~km}$ from Lake Pampulha (Figure 1). This station provides nebulosity data three times a day $(0 \mathrm{~h}, 12 \mathrm{~h}$, and $18 \mathrm{~h})$ and these values were linearly interpolated to hourly values for simulation.

The most recent Lake Pampulha bathymetry was measured by PBH in November 2014. Based on the bathymetry data (Figure 2), the reservoir can be divided into four regions: (i) the upstream channel of Ressaca and Sarandi streams, (ii) an upstream very shallow region (about $1.5 \mathrm{~m}$ depth), (iii) a transition region, where the depth varies from $1.5 \mathrm{~m}$ to almost $13 \mathrm{~m}$, and (iv) a deeper region further downstream. The inflow channel of the Ressaca and Sarandi streams was represented as thin dams in the model. In Delft3D-Flow, thin dams are infinitely thin and defined on the edges of elements. They prevent flow exchange between the two contiguous computational cells keeping the total wet surface and the volume of the model (Deltares, 2014). At station $\mathrm{P}_{1}\left(10 \mathrm{~m}\right.$ depth, Figure 1), located at $19^{\circ}$ 51 '5" south and $43^{\circ} 58^{\prime} 35^{\prime \prime}$ west, high-frequency water temperature monitoring (Table 3) was performed at the surface $(0.5 \mathrm{~m})$ at a time step of 30 minutes and at $2.5 \mathrm{~m}, 5.5 \mathrm{~m}$ and $9.5 \mathrm{~m}$ depth at a

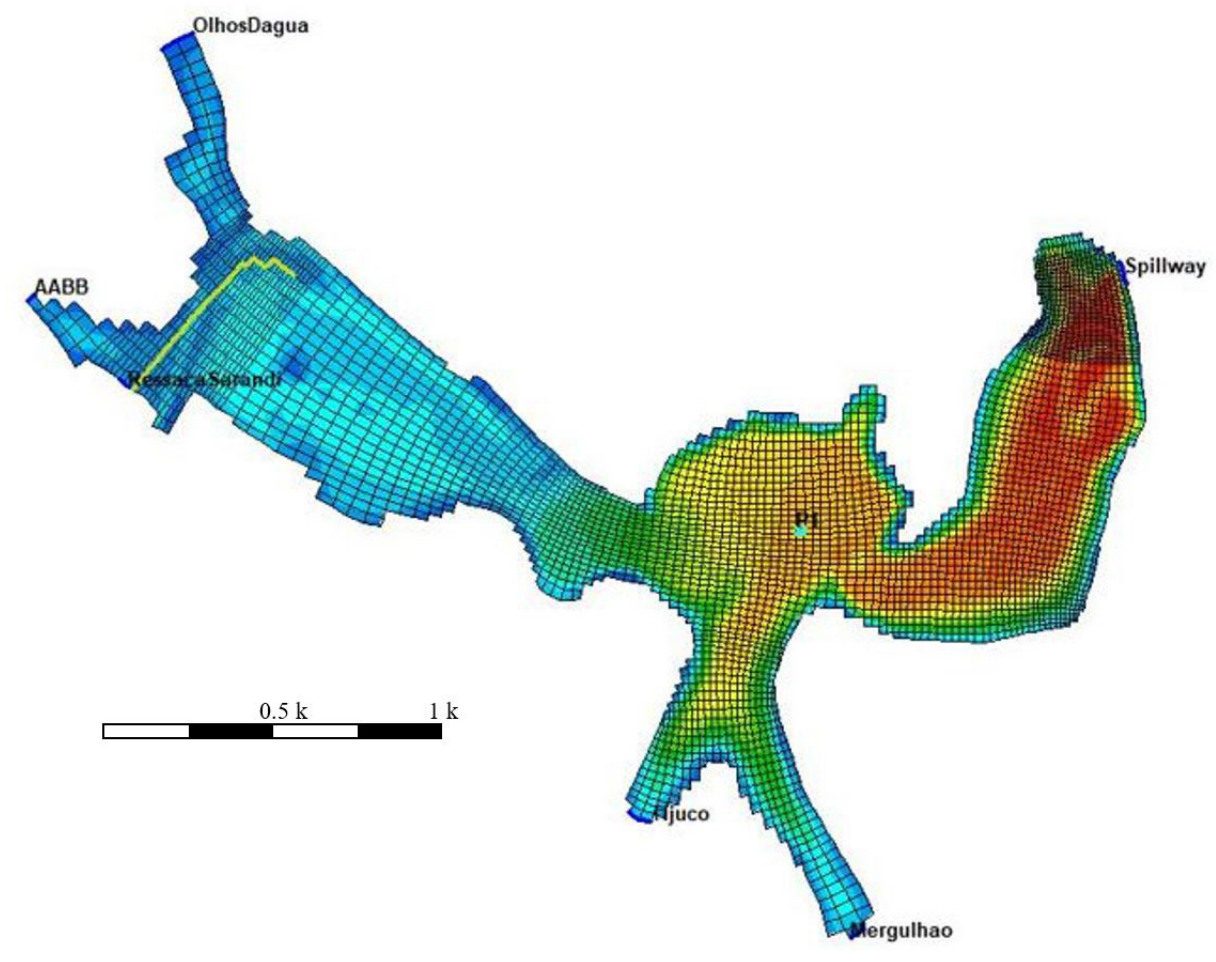

Bathymetry $[\mathrm{m}]$

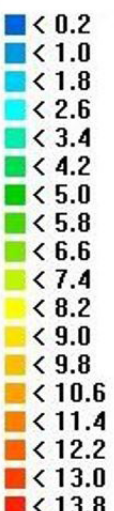

Figure 2. Lake Pampulha bathymetry, inflow location, thin dam location (yellow line), monitoring point (P1 - cyan cross) and spillway and inflow locations (blue lines).

Table 3. Characteristics of measuring devices at Lake Pampulha P1 station.

\begin{tabular}{cccccccc}
\hline Variable & $\begin{array}{c}\text { Sensor } \\
\text { manufacturer }\end{array}$ & $\begin{array}{c}\text { Monitoring } \\
\text { Depth }\end{array}$ & $\begin{array}{c}\text { Monitoring } \\
\text { period }\end{array}$ & Frequency & $\begin{array}{c}\text { Measuring } \\
\text { Range }\end{array}$ & $\begin{array}{c}\text { Sensor } \\
\text { Resolution }\end{array}$ & $\begin{array}{c}\text { Measuring } \\
\text { Precision }\end{array}$ \\
\hline $\begin{array}{c}\text { Water } \\
\text { Temperature }\end{array}$ & NKE & $0.5 \mathrm{~m}$ & $\begin{array}{c}05 / 2015 \text { to } \\
06 / 2016\end{array}$ & 1 hour & & \\
& & $2.5,5.5,9.5 \mathrm{~m}$ & $\begin{array}{c}02 / 2016 \text { to } \\
06 / 2016\end{array}$ & 1 hour & $-5{ }^{\circ} \mathrm{C}$ to $+35^{\circ} \mathrm{C}$ & $0.05{ }^{\circ} \mathrm{C}$ & $0.020^{\circ} \mathrm{C}$ at $20{ }^{\circ} \mathrm{C}$ \\
\hline
\end{tabular}


1-hour time step in 2015 and 2016 (monitoring performed within MAPLU-2 research project). Water transparency was measured using a Secchi Disk at a monthly frequency.

\section{Hydrodynamic modelling}

The three-dimensional hydrodynamic model Delft3D-Flow was used. It solves in three dimensions the Reynolds Averaged Navier-Stokes (RANS) equations for an incompressible fluid, under the shallow water and the Boussinesq assumptions. In the vertical, a hydrostatic pressure equation is considered, and the velocities are computed from the continuity equation. The $\mathrm{k}-\varepsilon$ model, a second-order turbulence closure model was chosen. The model computes the horizontal and vertical turbulent coefficient by transport equation for the turbulent kinetic energy and kinetic energy dissipation based in Kolmogorov and Prandtl concept. A full description can be found in Deltares (2014) section 9.4.2.

Hourly data of water temperature were used to calibrate the parameters of the heat exchange module included in the three-dimensional model. Thus, the heat exchange main equations (Deltares, 2014), will be presented. In the model, the heat exchange module is named as "Ocean". The heat exchange at the free surface is considered as resulting from the separate effects of solar (short wave) and atmospheric (longwave) radiation, and heat loss, represented in terms of back radiation, evaporation and convection. The total heat flux ( $\left.Q_{t o t}\right)$ through the free surface is calculated according to Equation 1.

$Q_{t o t}=Q_{s n}+Q_{a n}-Q_{b r}-Q_{e v}-Q_{c o}$

where $Q_{s n}=$ net incident solar radiation $\left(\mathrm{J} / \mathrm{m}^{2} . \mathrm{s}\right.$ ) (short wave), $Q_{a n}=$ net incident atmospheric radiation $\left(\mathrm{J} / \mathrm{m}^{2} . \mathrm{s}\right)$ (long wave), $Q_{b r}=$ back radiation $\left(\mathrm{J} / \mathrm{m}^{2} . \mathrm{s}\right.$ ) (long wave), $Q_{e v}=$ evaporative heat flux $\left(\mathrm{J} / \mathrm{m}^{2} . \mathrm{s}\right)$ (latent heat), $Q_{c o}=$ convective heat flux $\left(\mathrm{J} / \mathrm{m}^{2} . \mathrm{s}\right)$ (sensible heat).

The net incident solar radiation flux $\left(Q_{s n}\right)$ that will reach water surface is calculated as a function of short wave radiation for a clear sky condition, in which a part is reflected by the water surface (surface Albedo) and the magnitude is reduced by cloud cover (Equation 2).

$Q_{s n}=(1-\alpha) Q_{s c} *\left(1-0,4 F_{C}-0,38 F_{C}^{2}\right)$

Where $\alpha$ is the albedo reflection coefficient (dimensionless), $Q_{s c}$ is the solar radiation for a clear sky condition $\left(\mathrm{J} / \mathrm{m}^{2} . \mathrm{s}\right)$ and $F_{C}$ is the sky clouds that cover the sky (\%). The albedo coefficient used was 0,06 (default value) and the time series of solar radiation and cloud cover are input data.

Concerning the long wave radiations, the difference between the back radiation $\left(Q_{b r}\right)$ and the net incident atmospheric radiation $\left(Q_{a n}\right)$ is the effective back radiation, computed by the Equation 3 .

$Q_{e b}=Q_{b r}-Q_{a n}=5.58 * 10^{-8} T_{S}^{4} *\left(0.39-0.05 \sqrt{e_{a}}\right) *\left(1-0.6 F_{C}^{2}\right)$

where $T_{S}$ is the water surface temperature $\left({ }^{\circ} \mathrm{C}\right)$ and $e_{\boldsymbol{a}}$ is the vapour pressure (mbar).
Not all the radiation is absorbed at the water surface. A portion is transmitted to deeper water. The absorption of radiation in the water column is calculated by an exponential decay function (Lambert-Beer law). The evaporative heat flux $\left(Q_{e v}\right)$ is composed by a forced convection term (Qev,forced), caused by wind, and by a free convection term $\left(\mathrm{Qev}_{\text {ffree }}\right)$, due to buoyant forces from density differences between air and water (Equation 4).

$$
Q_{e v}=Q_{e v, \text { forced }}+Q_{e v, \text { free }}
$$

The forced convection of latent heat is calculated according Equation 5.

$$
Q_{e v, \text { forced }}=L_{v} \rho_{a} f\left(U_{10}\right)\left\{q_{S}\left(T_{S}\right)-q_{a}\left(T_{a}\right)\right\}
$$

where $L_{v}$ is the latent heat of vaporisation $(J / k g), \varrho_{a}$ is the air density $\left(\mathrm{kg} / \mathrm{m}^{3}\right), \mathrm{q}_{\mathrm{s}}$ (dimensionless) and $\mathrm{q}_{\mathrm{a}}$ (dimensionless) are the specific humidity of respectively saturated air and remote air (10 $\mathrm{m}$ above water level), $T_{S}$ is the water surface temperature $\left({ }^{\circ} \mathrm{C}\right), T_{a}$ is the air temperature $\left({ }^{\circ} \mathrm{C}\right)$ and $f\left(U_{10}\right)$ is the wind $(\mathrm{m} / \mathrm{s})$ function (Equation 6).

$$
f\left(U_{10}\right)=c_{e} U_{10}
$$

where $c_{e}$ is the Dalton number (dimensionless) and $U_{10}$ is the wind velocity $(\mathrm{m} / \mathrm{s})$ measured at $10 \mathrm{~m}$ height.

The free convection of latent heat is calculated according Equation 7.

$$
Q_{e v, \text { free }}=\left[0.14\left\{\frac{g \vartheta_{a i r}^{2}}{0.7^{2} \overline{\rho_{a}}}\right\}\left(\rho_{a 10}-\rho_{a 0}\right)\right]^{1 / 3} \overline{\rho_{a}} L_{v}\left(q_{S}\left(T_{S}\right)-q_{a}\left(T_{a}\right)\right.
$$

The convective heat flux (sensible heat), is also composed by a forced (Equation 8) and free term (Equation 9).

$$
Q_{c o, \text { forced }}=\rho_{a} c_{p} c_{H} U_{10}\left(T_{s}-T_{a}\right)
$$

Where $\rho_{a}$ is the air density $\left(\mathrm{kg} / \mathrm{m}^{3}\right), c_{p}$ is the specific heat of air $\left(0.24 \mathrm{cal} /\left(\mathrm{g}^{\circ} \mathrm{C}\right)\right), c_{H}$ is the Stanton number (dimensionless) and $U_{10}$ is the wind velocity $(\mathrm{m} / \mathrm{s})$ measured at $10 \mathrm{~m}$ height.

$Q_{c o, \text { free }}=\left[0.14\left\{\frac{g \vartheta_{\text {air }}^{2}}{0.7^{2} \overline{\rho_{a}}}\right\}\left(\rho_{a 10}-\rho_{a 0}\right)\right]^{1 / 3} \overline{\rho_{a}} c_{p}\left(T_{s}-T_{a}\right)$

where $g$ is the acceleration of gravity $\left(\mathrm{m} / \mathrm{s}^{2}\right), \vartheta_{\text {air }}$ is the air viscosity $\left(\mathrm{m}^{2} / \mathrm{s}\right), \rho_{a 0}$ is the saturated air density $\left(\mathrm{kg} / \mathrm{m}^{3}\right), \rho_{a 10}$ is the remote air density $(10 \mathrm{~m}$ above water level $)\left(\mathrm{kg} / \mathrm{m}^{3}\right), \overline{\rho_{a}}$ is the average air density $\left(\mathrm{kg} / \mathrm{m}^{3}\right), c_{p}$ is the specific heat of $\operatorname{air}(\mathrm{J} /(\mathrm{kgC}))$.

Wind intensity and direction measurements, used as uniform in the computation domain (spatial variations of wind speed were not considered), are carried out $10 \mathrm{~m}$ above the ground. Therefore, for the wind at lake surface $\left(\mathrm{U}_{\text {Lakesurface }}\right)$ an evaluation of a correction factor $(\mathrm{k})$ of wind intensity was applied (Equation 10). Wind factor values were tested in a range of $40 \%$ higher and $40 \%$ lower than measured values, varying by $20 \%$ for each simulation. According Jöhnk et al. (2008), due to lake geometry and terrain roughness 
between the lake and the meteorologic station the wind intensity required to be calibrated. Dalton coefficient, Stanton coefficient, horizontal viscosity and diffusivity were also estimated during the model calibration. Table 4 present the range values tested.

$U_{\text {Lakesurface }}=U_{10} * k$

\section{Model setup}

The model requires a computation domain and the specification of boundary and initial conditions. Lake Pampulha was discretized in ten vertical layers and 4019 horizontal grid elements (40190 elements in total). The mesh size varies from 50x20 to 10x10 m (Figure 2). Near the dam and Ressaca and Sarandi inflow the mesh was refined to account for likely higher water current velocities due to inflow and outflow regions.

Bathymetry of Lake Pampulha (Figure 2) greatly varies from upstream to downstream. During calibration of the hydrodynamic model the $\sigma$-grid and Z-grid options were used to compare the model performance and the influence of the grid type. The Z-grid option does not change the thickness of each vertical layers, which may help to represent the thermocline depth and water stratification. The $\sigma$-grid option has the advantage to preserve the number of active layers along the whole grid. Thus, in the shallower part of the lake the vertical resolution was higher $(0.15 \mathrm{~cm})$. At monitoring point P1, the Z-grid and $\sigma$-grid were very close, with 1 -m thickness vertical layers (Figure 3). The $\sigma$-grid option allows to analyse the hydrodynamics at the lake bottom in a same layer in continuity. Otherwise, using the Z-grid option the bottom of the lake would be represented in different layers.

Outflow was concentrated in the free spillway located at the dam (Figure 2). The open downstream boundary was set as the spillway rating curve (Felisberto et al., 2015). Thus, the outflow discharge is defined according to the water level in the spillway. The simulated periods were performed during the dry season, with low inflow (maximum inflow was smaller than 2-year return period flow), representing a water level of about $10 \mathrm{~cm}$ higher than the spillway crest. Thus, the initial water level of the lake was considered as the same level of the spillway for all simulated periods.

The initial conditions for the reservoir water temperature at the beginning of each simulation period were obtained from the lake monitoring station. The simulations were initialized with vertically uniform temperature. For velocities, the water was supposed to be at rest as initial condition. For all simulations, the following constants were used: acceleration of gravity at $9.81 \mathrm{~m}^{2} / \mathrm{s}$, water density at $1000 \mathrm{~kg} / \mathrm{m}^{3}$, air density at $1 \mathrm{~kg} / \mathrm{m}^{3}$ and water salinity at $0.15 \mathrm{ppt}$ (calculated with the mean of field conductivity data from 2015 to 2016 in surface water using the PSS-78 (Practical Salinity Scale of 1978 or Sal78 function) formulated and adopted by UNESCO (1981). For bottom roughness, the Chezy formulation was chosen with uniform values of $65 \mathrm{~m}^{1 / 2} \cdot \mathrm{s}^{-1}$ with free slip condition in wall roughness.

According to Deltares (2014), turbulent viscosity and turbulent diffusion are calculated differently in the horizontal and vertical directions. In turbulent flows, the diffusion mechanism is not only performed by molecular motion, but also intensified by eddy motion. Thus, the diffusion coefficient is computed by adding turbulent viscosity to molecular. Vertical terms are very small compared to horizontal terms.

The Delft3D-Flow model uses background horizontal eddy viscosity and diffusivity coefficients to represent unresolved hydrodynamic processes not calculated by the turbulent model.

Measured Secchi depth presented almost no variation (between 0.20 and $0.35 \mathrm{~m}$, with a mean of $0.30 \mathrm{~m}$ ). Secchi depth was set as $0.3 \mathrm{~m}$.

\section{Calibration parameters}

The following parameters were calibrated: wind factor (Equation 10), Dalton coefficient (Equation 6), Stanton coefficient (Equation 8), background horizontal eddy viscosity and eddy diffusivity, using a trial-and-error method. The range of values (Table 4) were defined according literature review (Deltares, 2014; Scriban et al., 2015; Soulignac et al., 2017; Vinnå et al., 2017).

\section{Simulation periods}

The simulation periods were selected according to the following criteria: (a) vertical uniform temperature of the water

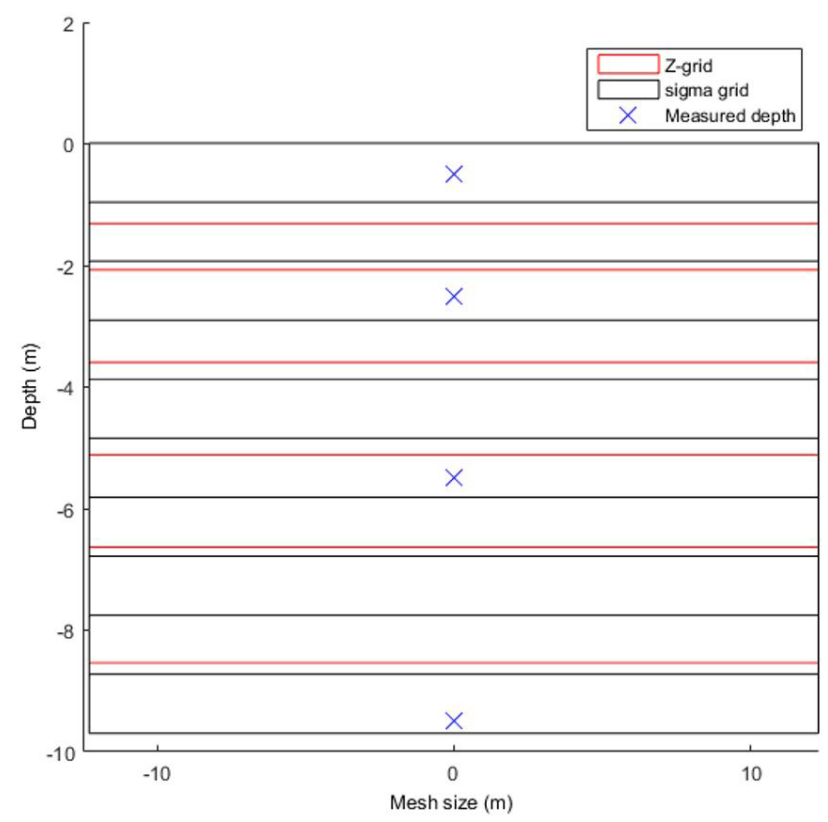

Figure 3. Vertical resolution for $\sigma$ and Z-grid in point P1. Blue $\mathrm{X}$ represents the measurement depths.

Table 4. Range of parameter values tested in calibration.

\begin{tabular}{cc}
\hline Parameter & Range tested in calibration \\
\hline Secchi (m) & - \\
Wind Factor $(-)$ & 0.40 to 1.40 \\
Background Horizontal Eddy & 0.0025 to 0.025 \\
Viscosity $\left(\mathrm{m}^{2} / \mathrm{s}\right)$ & \\
Background Horizontal Eddy & 0.0025 to 0.025 \\
Diffusivity $\left(\mathrm{m}^{2} / \mathrm{s}\right)$ & 0.0013 to 0.0007 \\
Dalton $(-)$ & 0.0007 to 0.0013 \\
Stanton $(-)$ & \\
\hline
\end{tabular}


column at the beginning of the period; and (b) occurrence of a thermal stratification during the period.

The calibration period lasted 18 days, from May $16^{\text {th }}$ to June $3^{\text {rd }} 2016$, corresponding to 440 hourly data of water temperature for each of the four depths $(0.5,2.5,5.5$ and $9.5 \mathrm{~m})$. The water temperature time series measured during this period at four depths at station $\mathrm{P} 1$, which has a maximum depth of $10 \mathrm{~m}$, is plotted in Figure 4. The period started with a mixed thermal condition of about $22.9^{\circ} \mathrm{C}$. This temperature value was set as the initial temperature condition for the lake simulation for all grid elements.

The validation period lasted 16 days, from May $29^{\text {th }}$ to June $14^{\text {th }} 2016$, corresponding to 388 hourly values of water temperature (Figure 4). The period started with a mixed thermal condition of about $22.2{ }^{\circ} \mathrm{C}$. Tributary inflows during the calibration and validation period are presented in Figure 5. A third period, from May $15^{\text {th }}$ to August $10^{\text {th }} 2015$ (90 days, 2107 hourly values), was simulated using the calibrated parameters in order to evaluate the model performance on a longer period. For this period, only subsurface temperature data is available (Figure 6). Tributary inflows during the period are presented in Figure 7. The meteorological variables, respectively in 2016 (calibration and validation) and 2015 (long validation period) are presented in Figure 8 and Figure 9. Figure 10 presents the box plot with minimum, first quartile, median, third quartile, and maximum values for each meteorological variable. During calibration and validation periods no precipitation were measured at the meteorological station near the lake (station A521, Figure 1). During the period of 2015 no significant precipitation was measured (maximum of $14.2 \mathrm{~mm} / \mathrm{h}$ on $27^{\text {th }}$ July). The effect of precipitation on the water temperature is not taken into account by the model. According to Figure 11, during the simulated periods, east wind direction is dominant on the reservoir.

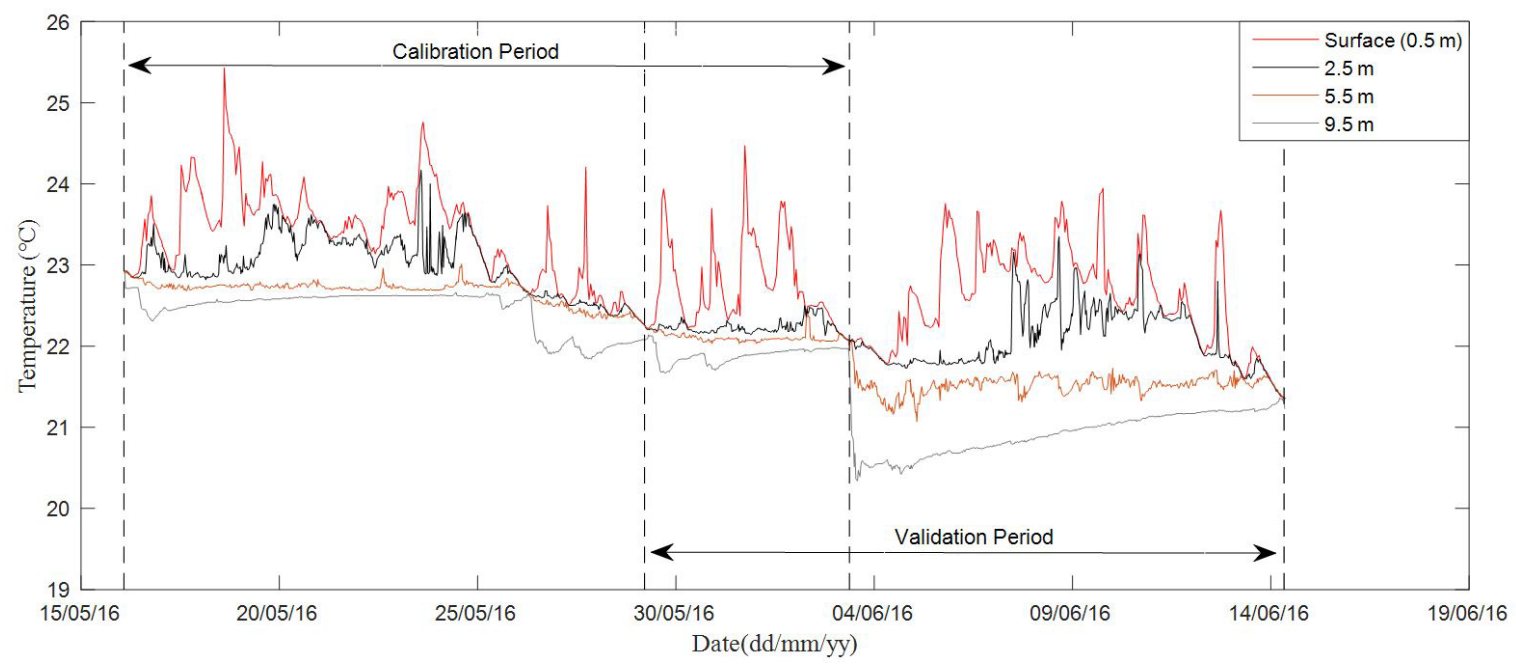

Figure 4. Water temperature $\left({ }^{\circ} \mathrm{C}\right)$ measured at point P1 for surface $(0.5 \mathrm{~m}), 2.5 \mathrm{~m}, 5.5 \mathrm{~m}$ and bottom $(9.5 \mathrm{~m})$ depth during the calibration period (May 16 $6^{\text {th }}$ to June $3^{\text {td }} 2016$ ) and validation period (May $29^{\text {th }}$ to June $14^{\text {th }} 2016$ ).

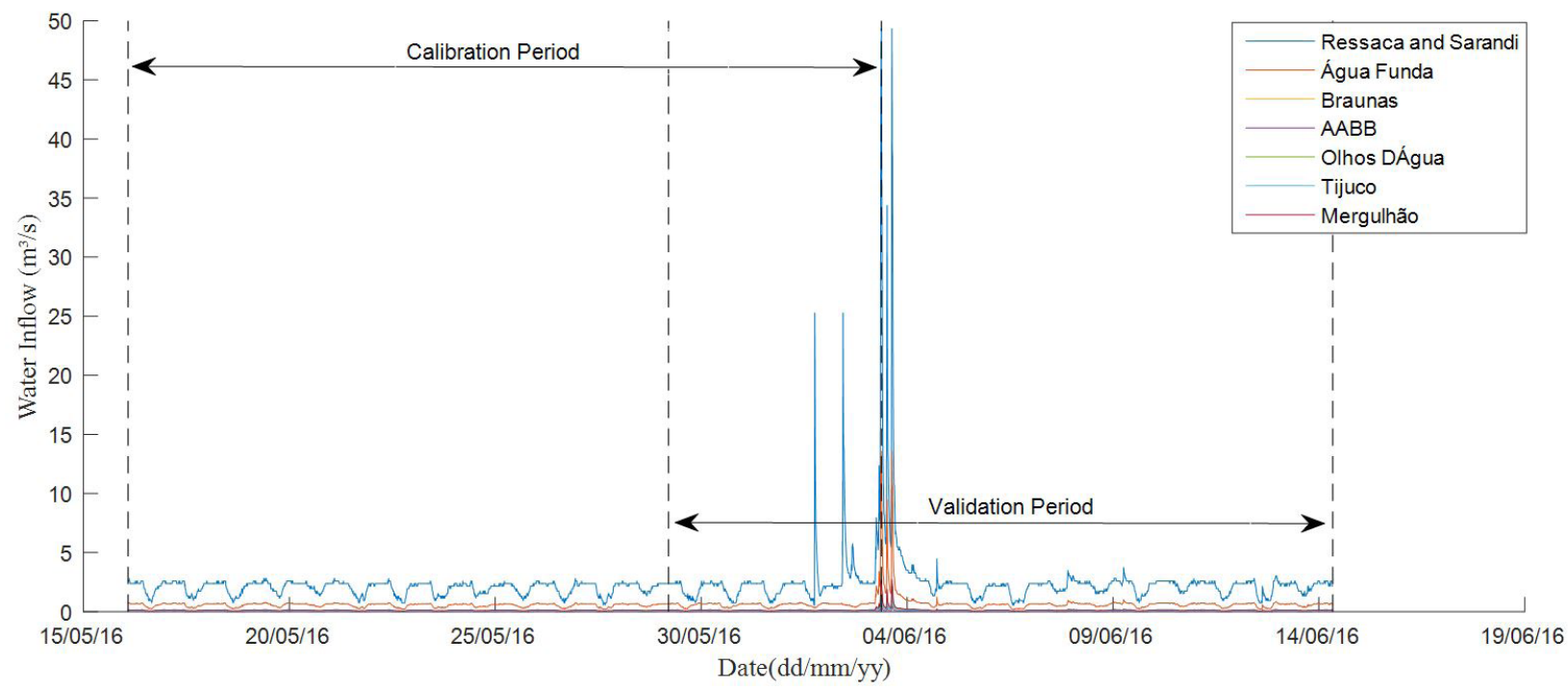

Figure 5. Tributaries inflow water during the calibration period (May $16^{\text {th }}$ to June $3^{\text {rd }} 2016$ ) and validation period (May $29^{\text {th }}$ to June $\left.14^{\text {th }} 2016\right)$. 

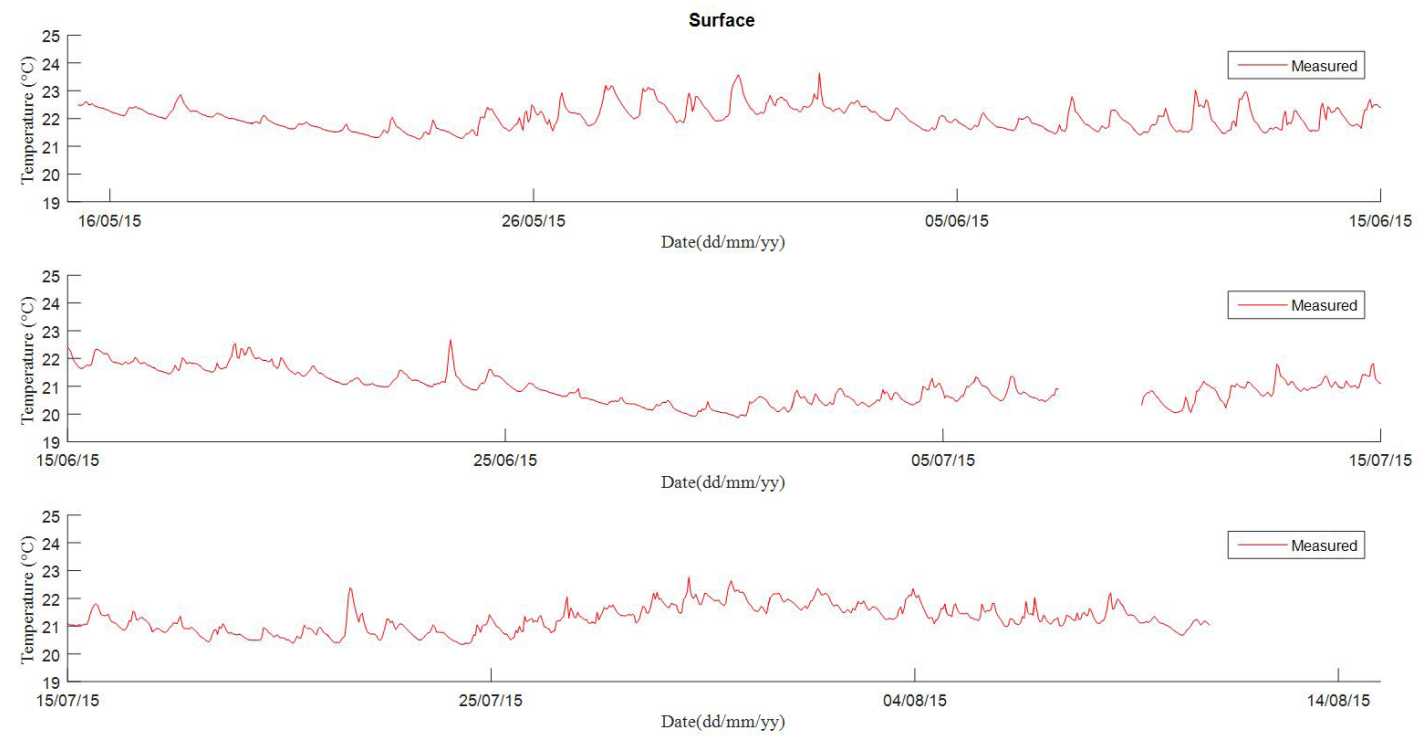

Figure 6. Measured temperature at P1 at surface $(0.5 \mathrm{~m})$ depth from May $15^{\text {th }} 2015$ to August $10^{\text {th }} 2015$.

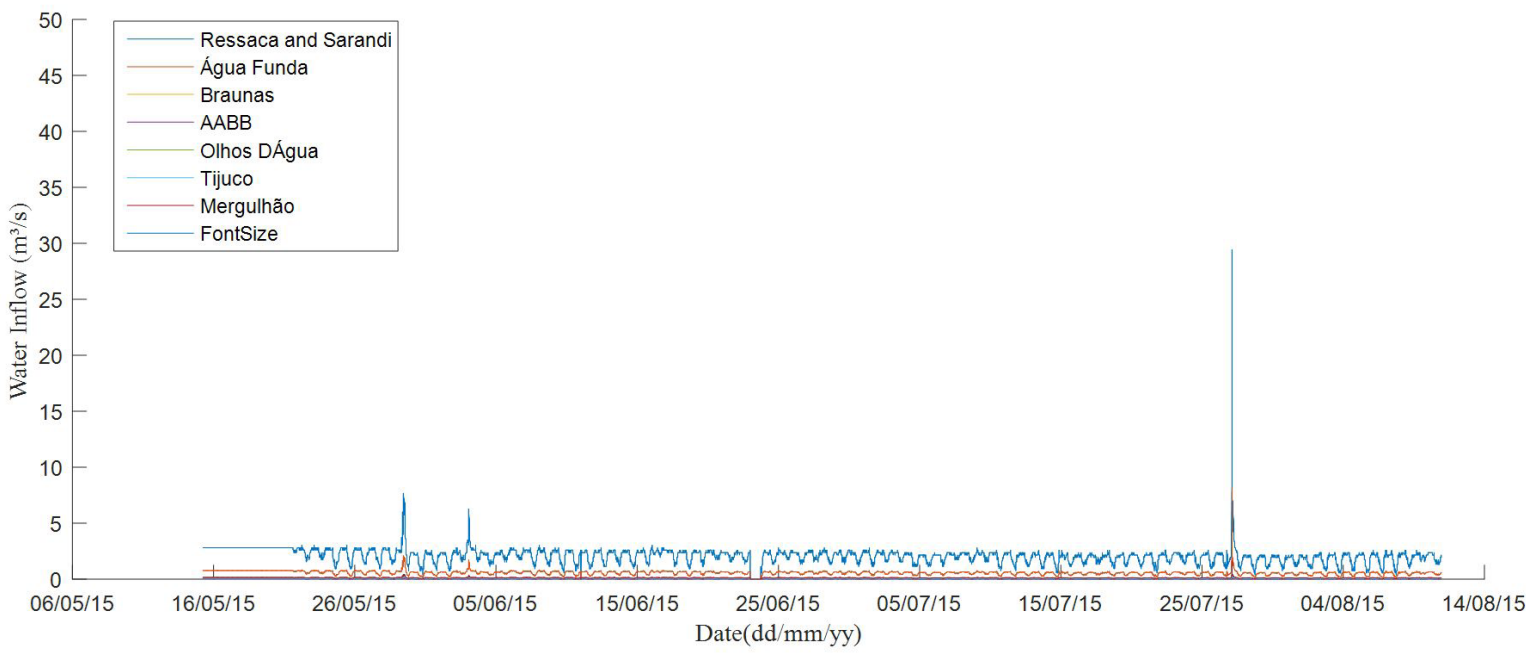

Figure 7.Tributaries inflow water from May 15 2015 to August $10^{\text {th }} 2015$.

\section{Performance indicators}

The hydrodynamic model performance during calibration and validation periods was assessed through comparison between measured and simulated water temperature. Four mathematical indicators were used to compare simulated and measured water temperature: the mean absolute error (MAE), the root mean square error (RMSE), the coefficient of determination $\left(\mathrm{R}^{2}\right)$ and the relative error (RE). These indicators were computed using hourly model outputs and hourly-averaged measurements.

Regarding the inflow water temperature estimation, the Nash-Sutcliffe efficiency coefficient, NSE (Equation 11) was used for assessing the goodness of fit. The NSE shows how well a model represents observed data variance compared to the mean value of observed data. NSE varies from - $\infty$ to 1 , the closer to the unity, the better the model performance. A NSE below zero indicates model estimation worse than the mean value of the observed data (Bennett et al., 2013).

$$
N S E=1-\frac{\frac{1}{n} \sum_{i=1}^{n}\left(y_{i}-y_{i}^{\prime}\right)^{2}}{\frac{1}{n} \sum_{i=1}^{n}\left(y_{i}-\bar{y}_{i}\right)^{2}}
$$

where $\mathrm{n}$ is the number of observations and the number model results, $y_{i}$ is the ith observation, $\bar{y}_{\mathrm{i}}$ is the mean value of observations and $y_{i}^{\prime}$ is the ith model result.

To analyse the impact of the stream inflow in the lake thermal stratification, Schmidt stability index and Lake number were computed using Lake Analyzer (Read et al. (2011). 

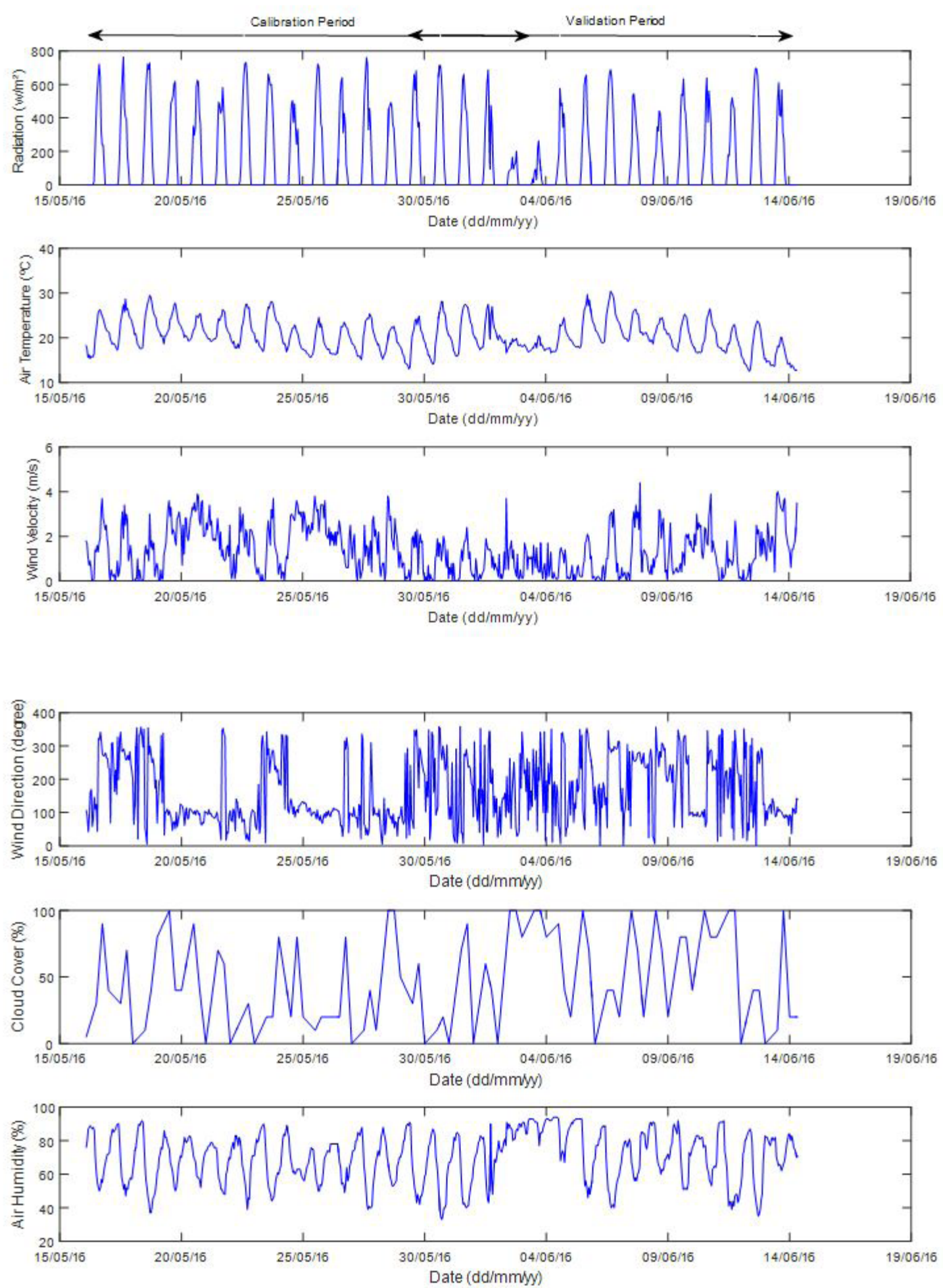

Figure 8. Radiation, air temperature, wind intensity and direction, cloud cover and humidity measured at a meteorology station during the calibration period (May 16 $6^{\text {th }}$ to June $3^{\text {rd }} 2016$ ) and validation period (May 29 ${ }^{\text {th }}$ to June $14^{\text {th }} 2016$ ).

\section{RESULTS}

\section{Inflow water temperature}

The hourly water inflow temperature was estimated from air temperature using linear regression and MSSWF method. Root mean square error (RMSE), the coefficient of determination $\left(\mathrm{R}^{2}\right)$ and the Nash-Sutcliffe efficiency (NSE) were used to compare the results of linear regression and of the MSSWF method (Chen \& Fang, 2016). Compared to MSSWF, linear regression presented better values for all indicators (Table 5). The hourly inflow temperature was computed using a linear regression with air temperature (Equation 12). 

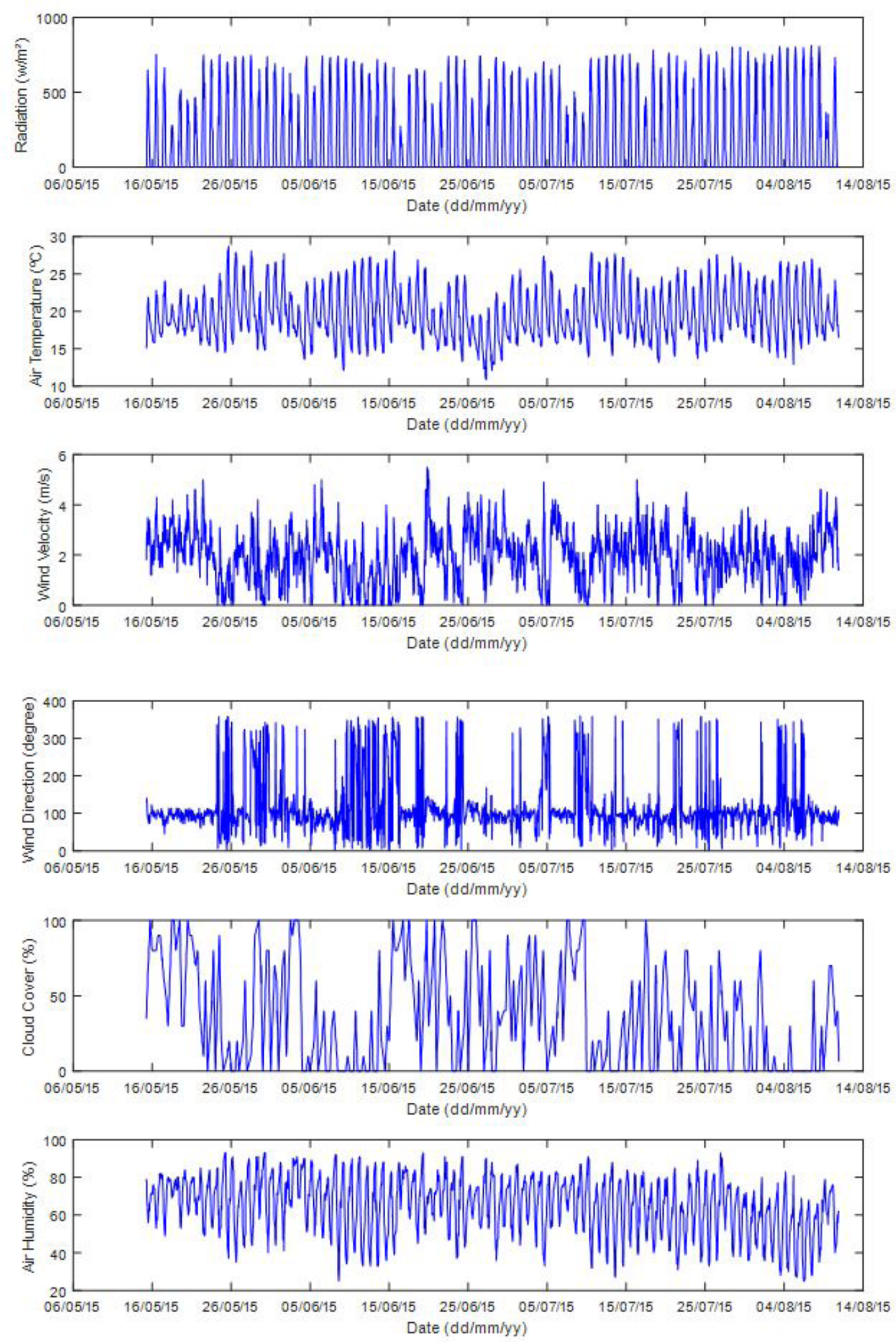

Figure 9. Radiation, air temperature, wind velocity and direction, cloud cover and humidity measured at the meteorology station during May $15^{\text {th }} 2015$ to August $10^{\text {th }} 2015$.

\section{$W T=0.72 * \operatorname{Air} T+3.37$}

where $W T$ is the water temperature $\left({ }^{\circ} \mathrm{C}\right)$ and $\operatorname{Air} T$ is the air temperature $\left({ }^{\circ} \mathrm{C}\right)$.

\section{Model calibration}

In the calibration step, wind factor values were tested for a range from $40 \%$ higher to $40 \%$ lower than 1 , varying by $20 \%$. For all 

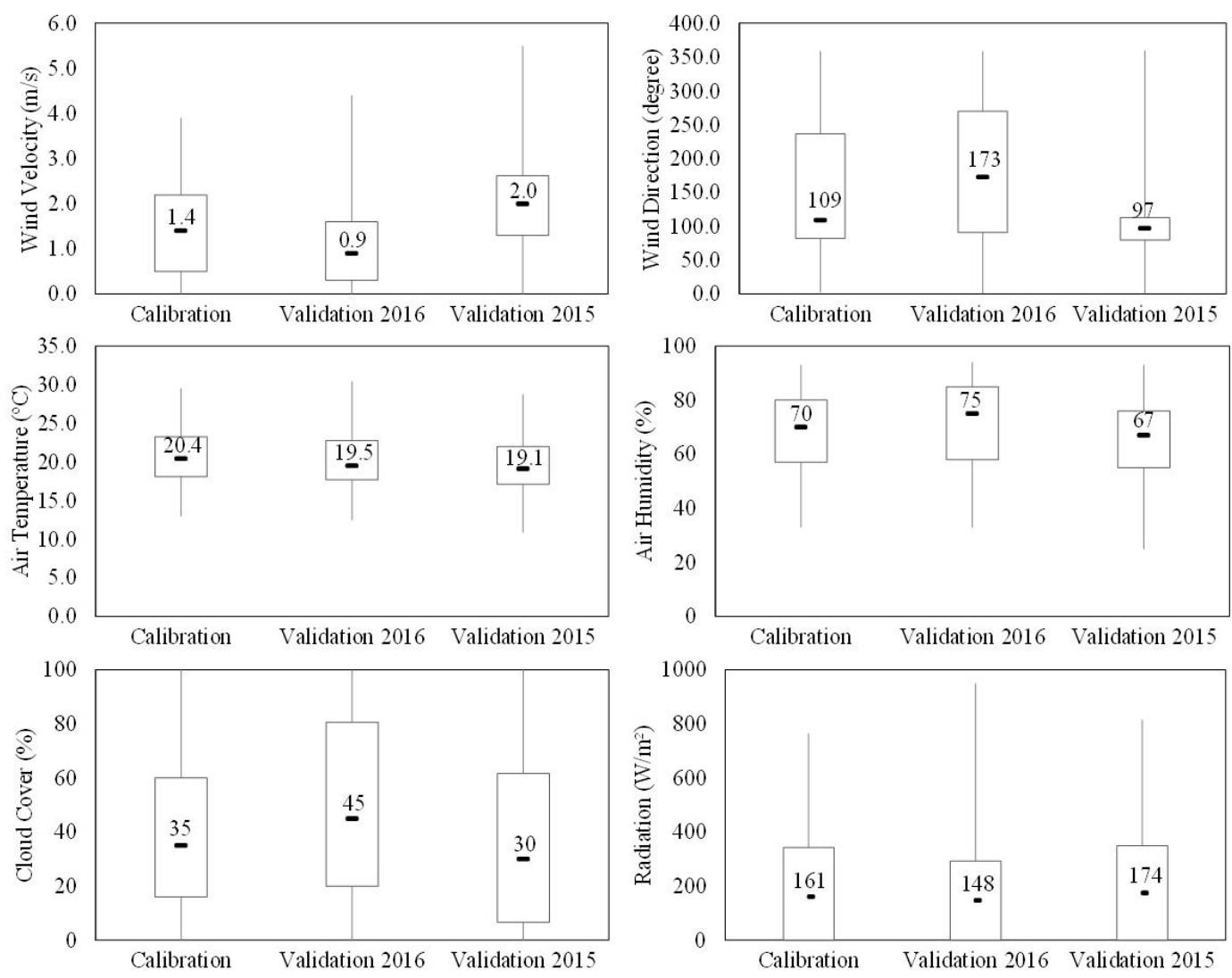

Figure 10. Wind velocity and direction, Air temperature and humidity, Cloud Cover and Radiation measured in the meteorology station for Calibration (May 16 ${ }^{\text {th }}$ to June $3^{\text {td }}$ 2016), Validation 2016 (May 29 th to June 14 ${ }^{\text {th }} 2016$ ) and Validation 2015 (May $15^{\text {th }}$ to August $10^{\text {th }}$ 2015).
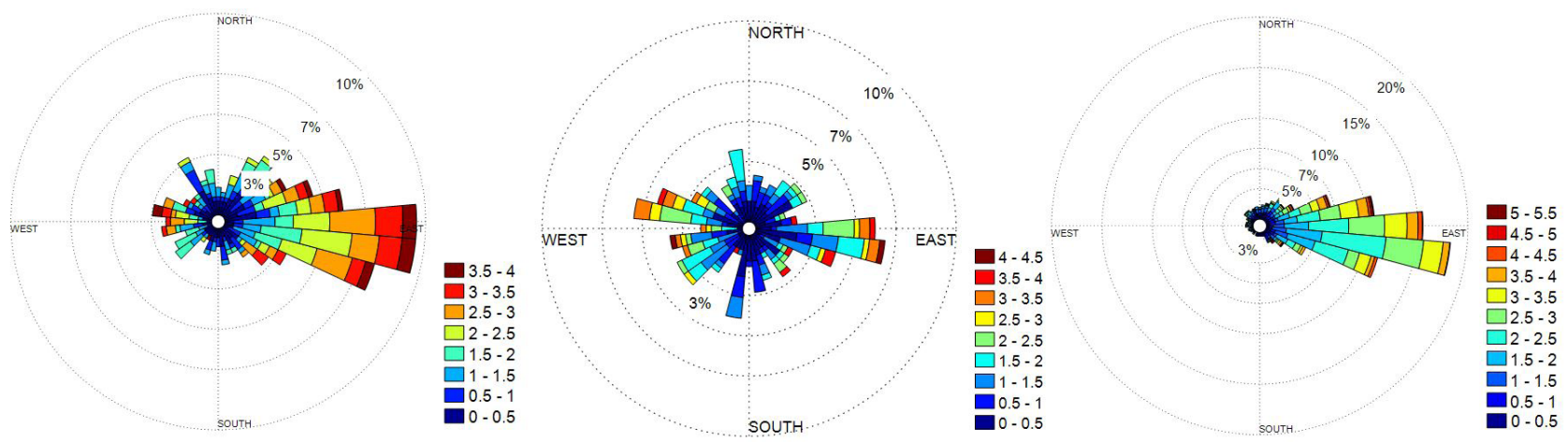

Figure 11. Wind direction (degree) and velocity $(\mathrm{m} / \mathrm{s})$ : Calibration period (May 16 ${ }^{\text {th }}$ to June $3^{\text {rd }} 2016$ ), Validation period in 2016 (May 29 ${ }^{\text {th }}$ to June $14^{\text {th }}$ 2016) and Validation period in 2015 (May $15^{\text {th }}$ to August $10^{\text {th }} 2015$ ).

Table 5. Mathematical indicators for the hourly water temperature estimation methods.

\begin{tabular}{ccc}
\hline Method & Indicators & Values \\
\hline Linear Regression & $\operatorname{RMSE~}\left({ }^{\circ} \mathrm{C}\right)$ & 1.02 \\
& $\mathrm{R}^{2}$ & 0.82 \\
MSSWF & $\mathrm{NSE}$ & 0.82 \\
& $\mathrm{RMSE}\left({ }^{\circ} \mathrm{C}\right)$ & 1.50 \\
& $\mathrm{R}^{2}$ & 0.75 \\
$\mathrm{NSE}$ & 0.56 \\
\hline
\end{tabular}

depths, the better adjustment between measured and simulated temperature values were obtained for the lower wind factor (0.6), however with no significant differences (Table 6). At the water surface, the simulated values presented a higher variation compared to the measured values for all wind factors. For the 2.5, 5.5 and $9.5 \mathrm{~m}$ depths, a systematic error occurs after May $25^{\text {th }} 2016$. The simulated water temperature is colder than the measured values.

Setting wind intensity equal to the measured values (wind intensity factor equal to 1), the Dalton and Stanton coefficients 
Thermal functioning of a tropical reservoir assessed through three-dimensional modelling and high-frequency monitoring

Table 6. Mathematical indicators for temperature with different values of wind intensity correction factor (dimensionless).

\begin{tabular}{|c|c|c|c|c|c|c|}
\hline Depth (m) & Indicator & 1.40 & 1.20 & 1.00 & 0.80 & 0.60 \\
\hline \multirow[t]{4}{*}{0.5} & $\operatorname{MAE}\left({ }^{\circ} \mathrm{C}\right)$ & 0.53 & 0.44 & 0.39 & 0.36 & 0.37 \\
\hline & RMSE $\left({ }^{\circ} \mathrm{C}\right)$ & 0.60 & 0.51 & 0.45 & 0.43 & 0.45 \\
\hline & RE $(\%)$ & 2.29 & 1.9 & 1.67 & 1.56 & 1.57 \\
\hline & $\mathrm{R}^{2}$ & 0.76 & 0.76 & 0.77 & 0.76 & 0.73 \\
\hline \multirow[t]{4}{*}{2.5} & $\operatorname{MAE}\left({ }^{\circ} \mathrm{C}\right)$ & 0.43 & 0.38 & 0.33 & 0.28 & 0.22 \\
\hline & RMSE $\left({ }^{\circ} \mathrm{C}\right)$ & 0.50 & 0.44 & 0.38 & 0.33 & 0.27 \\
\hline & RE $(\%)$ & 1.90 & 1.66 & 1.45 & 1.24 & 0.99 \\
\hline & $\mathrm{R}^{2}$ & 0.81 & 0.82 & 0.84 & 0.83 & 0.85 \\
\hline \multirow[t]{4}{*}{5.5} & $\operatorname{MAE}\left({ }^{\circ} \mathrm{C}\right)$ & 0.40 & 0.34 & 0.29 & 0.23 & 0.17 \\
\hline & RMSE $\left({ }^{\circ} \mathrm{C}\right)$ & 0.50 & 0.41 & 0.36 & 0.29 & 0.22 \\
\hline & RE $(\%)$ & 1.77 & 1.50 & 1.27 & 1.00 & 0.77 \\
\hline & $\mathrm{R}^{2}$ & 0.89 & 0.88 & 0.93 & 0.94 & 0.95 \\
\hline \multirow[t]{4}{*}{9.5} & $\operatorname{MAE}\left({ }^{\circ} \mathrm{C}\right)$ & 0.46 & 0.40 & 0.35 & 0.29 & 0.24 \\
\hline & RMSE $\left({ }^{\circ} \mathrm{C}\right)$ & 0.57 & 0.51 & 0.45 & 0.38 & 0.32 \\
\hline & RE (\%) & 2.05 & 1.81 & 1.55 & 1.30 & 1.07 \\
\hline & $\mathrm{R}^{2}$ & 0.89 & 0.89 & 0.89 & 0.89 & 0.89 \\
\hline
\end{tabular}

were changed separately. A decrease of the Stanton coefficient to 0.0007 (almost 50\% lower) did not result in significant changes (maximum temperature decreased less than $0.1{ }^{\circ} \mathrm{C}$ ). Thus, the default value of 0.0013 was chosen. Water surface cooling was smaller for lower Dalton coefficients during the night due to lower heat loss. The water surface temperature remaining warmer during the night resulted in warmer temperature at greater depths. Thus, the systematic error (colder simulated temperature for deeper depths) was reduced especially after May $26^{\text {th }} 2016$.

The Z-grid option was also used to compare the influence of the grid type on the model performance. Using the Z-grid option, a non-homogenous vertical distribution was necessary to provide more active layers in the lake upstream region, avoiding numerical instabilities due to inflows. The results for the Z-grid and $\sigma$-grid were interpolated to the measuring depth.

The mathematical indicators are very similar (Table 7). The indicators using $\sigma$-grid are slightly better in surface $(0.5 \mathrm{~m})$ and $2.5 \mathrm{~m}$ depth for RE and MAE. Thus, the $\sigma$-grid was chosen.

The final parameter values are shown in Table 8. The calibration period started on May $16^{\text {th }} 2016$ with a uniform water temperature of $22.9^{\circ} \mathrm{C}$. Over the following ten days, the lake water column stratified with warming in the surface layer to around $25.3^{\circ} \mathrm{C}$. Mixing events (temperature difference between surface and bottom less than $0.25^{\circ} \mathrm{C}$ ) occurred on May $25^{\text {th }}$ and $26^{\text {th }} 2016$, with temperature decreasing to $22.6^{\circ} \mathrm{C}$. After May $26^{\text {th }}$, the temperature at $9.5 \mathrm{~m}$ depth decreased by almost $1^{\circ} \mathrm{C}$ and the surface temperature displayed daily warming. A third stratification period lasted three days, ending with a mixing event on May $29^{\text {th }}$ at $22.1^{\circ} \mathrm{C}$. During the whole period, the temperature difference between the surface and $9.5 \mathrm{~m}$ depth, at maximum stratification, was $2.9^{\circ} \mathrm{C}$ (May $18^{\text {th }}$ at $\left.15: 00\right)$.

Observed and simulated water temperatures at the four depths during the calibration period are presented in Figure 12. Figure 13 shows the difference between surface and bottom layer for measured and simulated water temperature. Figure 14 shows the temperature for the four depths in which measurements were carried out. Table 9 shows the number of days with a difference between surface $(0.5 \mathrm{~m})$ and bottom $(9.5 \mathrm{~m})$ for measurement and simulated temperatures of $0.25^{\circ} \mathrm{C}$ to $2.0^{\circ} \mathrm{C}$. According to
Table 7. Mathematical indicators for lake temperature using Z-grid and $\sigma$-grid option.

\begin{tabular}{|c|c|c|c|}
\hline \multirow{2}{*}{ Depth (m) } & \multirow{2}{*}{ Indicators } & \multicolumn{2}{|c|}{ Grid type } \\
\hline & & $\sigma$-grid & Z-grid \\
\hline \multirow[t]{4}{*}{0.5} & $\operatorname{MAE}\left({ }^{\circ} \mathrm{C}\right)$ & 0.30 & 0.40 \\
\hline & $\mathrm{RMSE}\left({ }^{\circ} \mathrm{C}\right)$ & 0.42 & 0.51 \\
\hline & RE (\%) & 1.30 & 1.68 \\
\hline & $\mathrm{R}^{2}$ & 0.73 & 0.72 \\
\hline \multirow[t]{4}{*}{2.5} & $\operatorname{MAE}\left({ }^{\circ} \mathrm{C}\right)$ & 0.15 & 0.18 \\
\hline & RMSE $\left({ }^{\circ} \mathrm{C}\right)$ & 0.20 & 0.21 \\
\hline & RE (\%) & 0.64 & 0.77 \\
\hline & $\mathrm{R}^{2}$ & 0.84 & 0.86 \\
\hline \multirow[t]{4}{*}{5.5} & $\operatorname{MAE}\left({ }^{\circ} \mathrm{C}\right)$ & 0.13 & 0.08 \\
\hline & RMSE $\left({ }^{\circ} \mathrm{C}\right)$ & 0.15 & 0.09 \\
\hline & $\mathrm{RE}(\%)$ & 0.56 & 0.34 \\
\hline & $\mathrm{R}^{2}$ & 0.93 & 0.95 \\
\hline \multirow[t]{4}{*}{9.5} & $\operatorname{MAE}\left({ }^{\circ} \mathrm{C}\right)$ & 0.16 & 0.16 \\
\hline & RMSE $\left({ }^{\circ} \mathrm{C}\right)$ & 0.18 & 0.19 \\
\hline & RE (\%) & 0.70 & 0.72 \\
\hline & $\mathrm{R}^{2}$ & 0.90 & 0.90 \\
\hline
\end{tabular}

Table 8. Set of parameter values for hydrodynamic simulation in Lake Pampulha.

\begin{tabular}{ccc}
\hline Parameter & Value & $\begin{array}{c}\text { Range tested in } \\
\text { calibration }\end{array}$ \\
\hline $\begin{array}{c}\text { Secchi }(\mathrm{m}) \\
\text { Wind Factor }(-)\end{array}$ & 0.3 (measured) & - \\
Background & 1.0 (calibrated) & 0.40 to 1.40 \\
Horizontal Eddy & 0.025 (calibrated) & 0.0025 to 0.025 \\
$\quad$ Viscosity $\left(\mathrm{m}^{2} / \mathrm{s}\right)$ & & \\
$\quad$ Background & & \\
Horizontal Eddy & 0.025 (calibrated) & 0.0025 to 0.025 \\
$\begin{array}{c}\text { Diffusivity }\left(\mathrm{m}^{2} / \mathrm{s}\right) \\
\text { Dalton }(-)\end{array}$ & 0.0007 (calibrated) & 0.0013 to 0.0007 \\
Stanton $(-)$ & 0.0013 (default) & 0.0007 to 0.0013 \\
\hline
\end{tabular}

both Figure 13 and Figure 14 and to Table 9, the model could accurately represent the main observed patterns: (i) the daily time scale of surface warming; (ii) the maximum stratification time, (iii) the cooling at the lake bottom on May $26^{\text {th }}$; (iv) the timing 

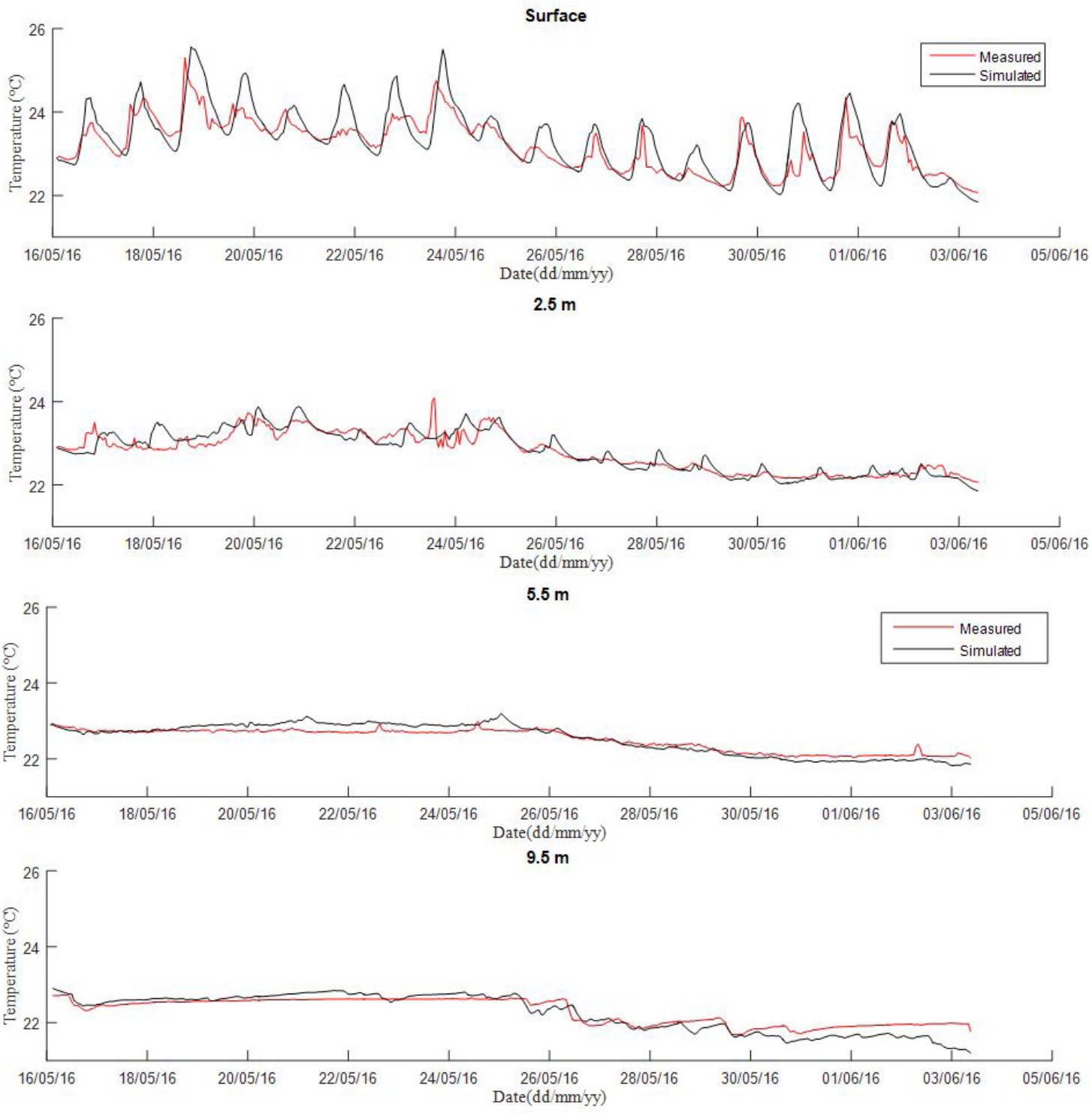

Figure 12. Measured and simulated temperatures for the calibration period from May $16^{\text {th }}$ to June $3^{\text {rd }} 2016$ at P1 station.

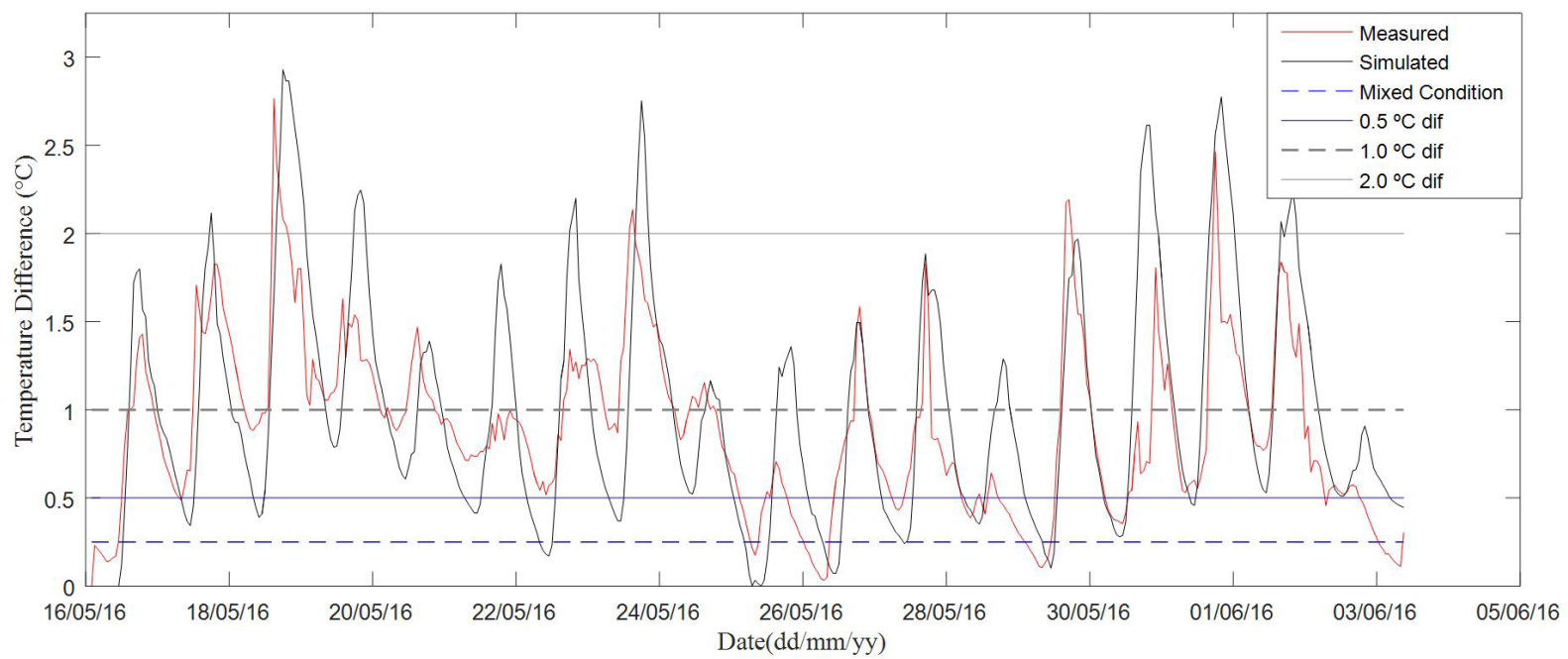

Figure 13. Difference of surface $(0.5 \mathrm{~m})$ and bottom $(9.5 \mathrm{~m})$ for measurement and simulated temperatures for the calibration period from May $16^{\text {th }}$ to June $3^{\text {rd }} 2016$ at P1 station. Blue dashed line represents a mixing condition with difference between surface and bottom of $0.25^{\circ} \mathrm{C}$ and grey lines represent differences of 1.0 and $2.0^{\circ} \mathrm{C}$. 


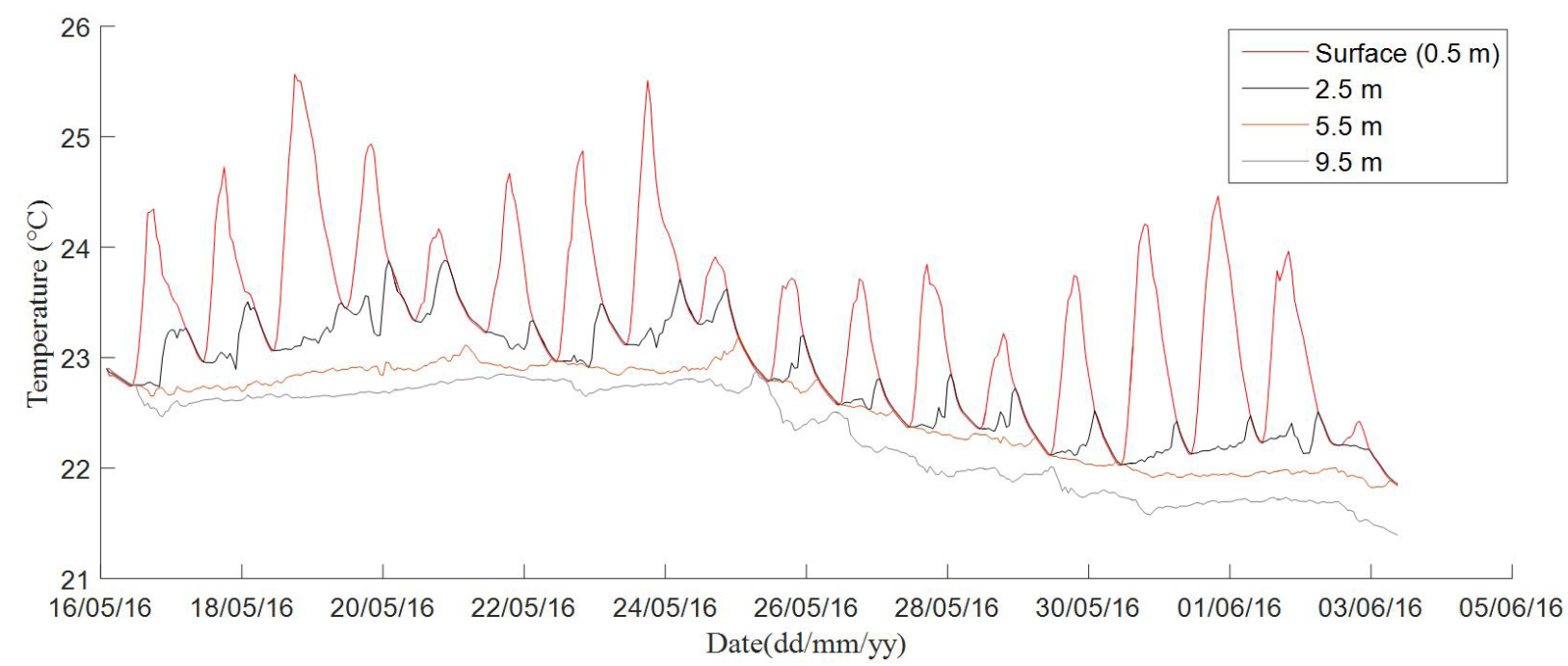

Figure 14 - Water temperature $\left({ }^{\circ} \mathbf{C}\right)$ simulated at point $\mathbf{P} 1$ for surface $(\mathbf{0 . 5} \mathrm{m}), 2.5 \mathrm{~m}, 5.5 \mathrm{~m}$ and bottom $(9.5 \mathrm{~m})$ depth during the calibration period (May 16 $6^{\text {th }}$ to June $3^{\text {rd }}$ 2016).

Table 9. Number of days with difference between surface $(0.5 \mathrm{~m})$ and bottom $(9.5 \mathrm{~m})$ for measurement and simulated temperatures for the calibration period from May $16^{\text {th }}$ to June $3^{\text {rd }} 2016$ at P1 station.

\begin{tabular}{ccc}
\hline Value & Measured & Simulated \\
\hline$\Delta \mathrm{T} \leq 0.25^{\circ} \mathrm{C}$ & 4 & 5 \\
$\Delta \mathrm{T} \leq 0.50^{\circ} \mathrm{C}$ & 9 & 13 \\
$\Delta \mathrm{T} \geq 1.0^{\circ} \mathrm{C}$ & 15 & 17 \\
$\Delta \mathrm{T} \geq 2.0^{\circ} \mathrm{C}$ & 4 & 8 \\
\hline
\end{tabular}

Table 10. Model performance indicators for the calibration and validation period.

\begin{tabular}{|c|c|c|c|}
\hline Depth (m) & $\begin{array}{c}\text { Performance } \\
\text { indicators }\end{array}$ & $\begin{array}{c}\text { Calibration } \\
\text { Period }\end{array}$ & $\begin{array}{l}\text { Validation } \\
\text { Period } 2016\end{array}$ \\
\hline \multirow[t]{4}{*}{ Surface $(0.5)$} & $\operatorname{MAE}\left({ }^{\circ} \mathrm{C}\right)$ & 0.30 & 0.34 \\
\hline & RMSE $\left({ }^{\circ} \mathrm{C}\right)$ & 0.42 & 0.45 \\
\hline & RE (\%) & 1.30 & 1.51 \\
\hline & $\mathrm{R}^{2}$ & 0.73 & 0.63 \\
\hline \multirow[t]{4}{*}{2.5} & $\operatorname{MAE}\left({ }^{\circ} \mathrm{C}\right)$ & 0.15 & 0.23 \\
\hline & RMSE $\left({ }^{\circ} \mathrm{C}\right)$ & 0.20 & 0.31 \\
\hline & RE (\%) & 0.64 & 1.04 \\
\hline & $\mathrm{R}^{2}$ & 0.84 & 0.41 \\
\hline \multirow[t]{4}{*}{5.5} & $\operatorname{MAE}\left({ }^{\circ} \mathrm{C}\right)$ & 0.13 & 0.12 \\
\hline & RMSE $\left({ }^{\circ} \mathrm{C}\right)$ & 0.15 & 0.16 \\
\hline & RE (\%) & 0.56 & 0.56 \\
\hline & $\mathrm{R}^{2}$ & 0.93 & 0.80 \\
\hline \multirow[t]{4}{*}{ Bottom (9.5) } & $\operatorname{MAE}\left({ }^{\circ} \mathrm{C}\right)$ & 0.16 & 0.20 \\
\hline & RMSE $\left({ }^{\circ} \mathrm{C}\right)$ & 0.18 & 0.24 \\
\hline & RE (\%) & 0.70 & 0.95 \\
\hline & $\mathrm{R}^{2}$ & 0.90 & 0.81 \\
\hline
\end{tabular}

of mixing episode on May $25^{\text {th }}, 26^{\text {th }}$ and on $29^{\text {th }}$, in which the difference between the measured and simulated temperature at the lake surface and bottom were respectively of $0.17,0.04{ }^{\circ} \mathrm{C}$ and $0.11^{\circ} \mathrm{C}$ for measurement and $0.03,0.07$ and 0.10 for simulation, (v) and the duration of stratification periods. Model performance indicators are presented in Table 10. For all depths, RMSE and
RE were quite good, with maximum values of $0.42{ }^{\circ} \mathrm{C}$ and $1.30 \%$, respectively. The maximum MAE was $0.30{ }^{\circ} \mathrm{C}$, representing a very good performance. The lower $\mathrm{R}^{2}$ value was 0.73 at water surface layer.

\section{Validation Period in 2016}

The model was run with the calibrated parameters values (Table 8). For all depths, the RMSE and RE between the measured and simulated values were good (Table 10 and Figure 15), with maximum values of $0.45^{\circ} \mathrm{C}$ and $1.51 \%$, respectively. The $\mathrm{R}^{2}$ ranged from 0.41 to 0.81 , also considered as a good result. The MAE presented a very good performance, with a maximum value of $0.34{ }^{\circ} \mathrm{C}$ at $0.5 \mathrm{~m}$. According to the mathematical indicators, the model can be considered validated.

The validation period in 2016 started on May $29^{\text {th }}$ with a uniform water temperature of $22.2{ }^{\circ} \mathrm{C}$. Over the first five days a daily stratification and mixing alternation was observed. According to Figure 16, on May $30^{\text {th }}$ the difference between surface and bottom temperature was $0.35{ }^{\circ} \mathrm{C}$ for measured values and 0.07 for simulated values. On May $31^{\text {st }}$, this difference was 0.53 and $0.31{ }^{\circ} \mathrm{C}$, on $1^{\text {st }}$ June it was 0.77 and $0.44{ }^{\circ} \mathrm{C}$ and $2^{\text {nd }}$ June 0.11 and $0.46{ }^{\circ} \mathrm{C}$, respectively for measured and simulated values. Until $5^{\text {th }}$ June, comparing with the measured values, the simulated water surface presented a good adjustment, however, after this date the simulated values presented higher amplitude with lower low values (Figure 15). This discrepancy resulted in higher differences between simulated surface and bottom water temperature (Figure 16).

On $3^{\text {rd }}$ June, the water temperature column was uniform around $22.0^{\circ} \mathrm{C}$. Then, four hours later, at 09:00 a strong cooling at 5.5 and $9.5 \mathrm{~m}$ depth occurred. At $9.5 \mathrm{~m}$ depth, the water temperature decreased by $1.8^{\circ} \mathrm{C}$ over 4 hours. At $5.5 \mathrm{~m}$ depth, the decrease was $0.8^{\circ} \mathrm{C}$ over 12 hours. After this cooling of the bottom layers, the water at $5.5 \mathrm{~m}$ depth remained at a relatively constant temperature of $21.5^{\circ} \mathrm{C}$ for the whole period. In contrast, 

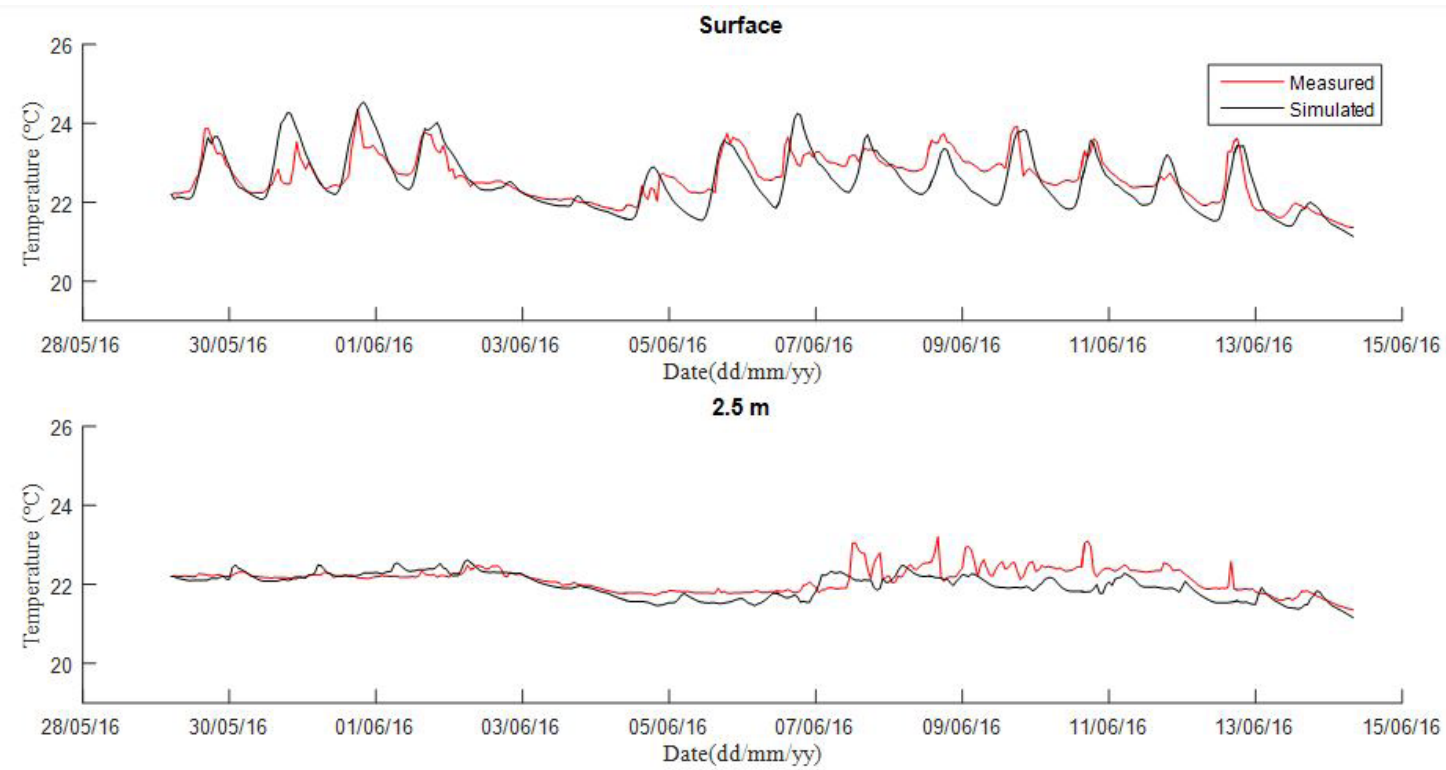

$5.5 \mathrm{~m}$
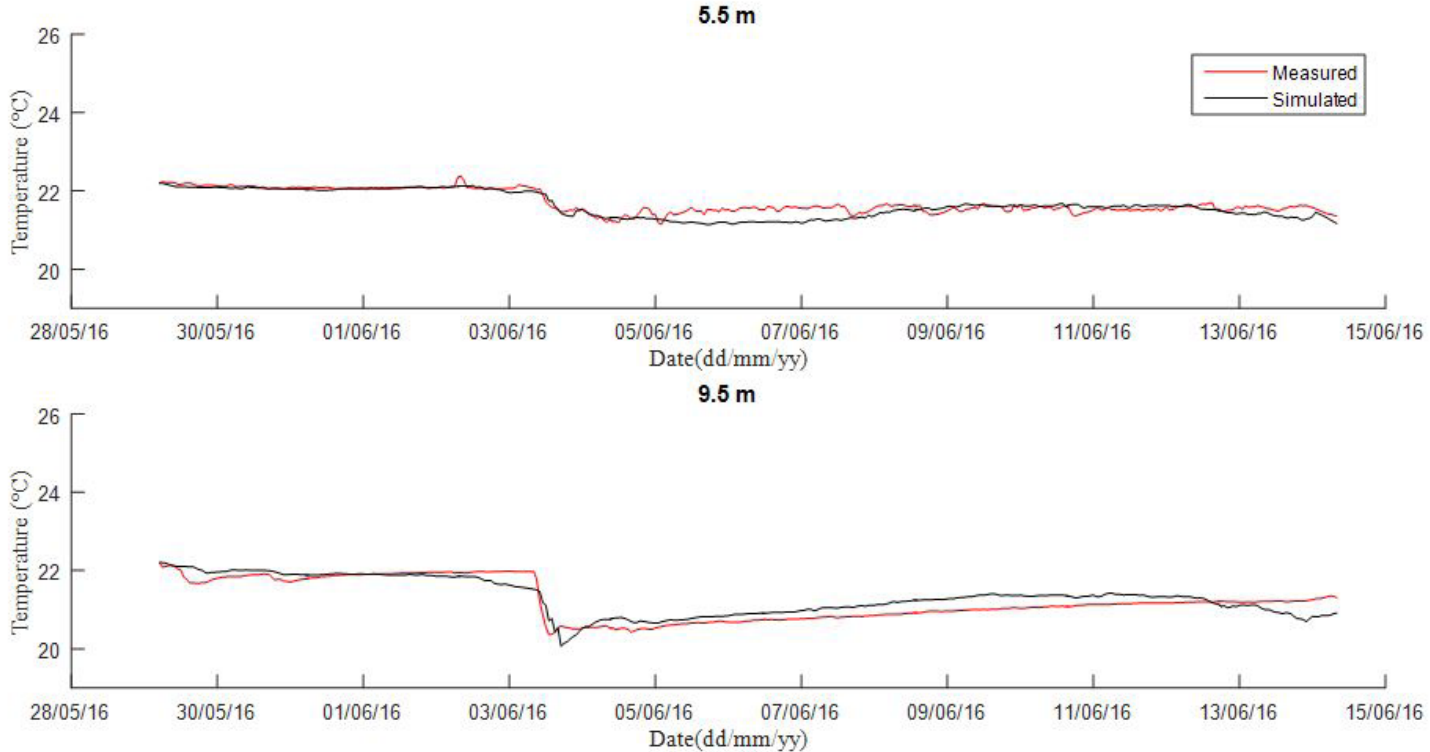

Figure 15. Measured and simulated temperature for the validation period (May $29^{\text {th }}$ to June $\left.14^{\text {th }} 2016\right)$ at surface $(0.5 \mathrm{~m}), 2.5 \mathrm{~m}, 5.5 \mathrm{~m}$ and $9.5 \mathrm{~m}$ depths.

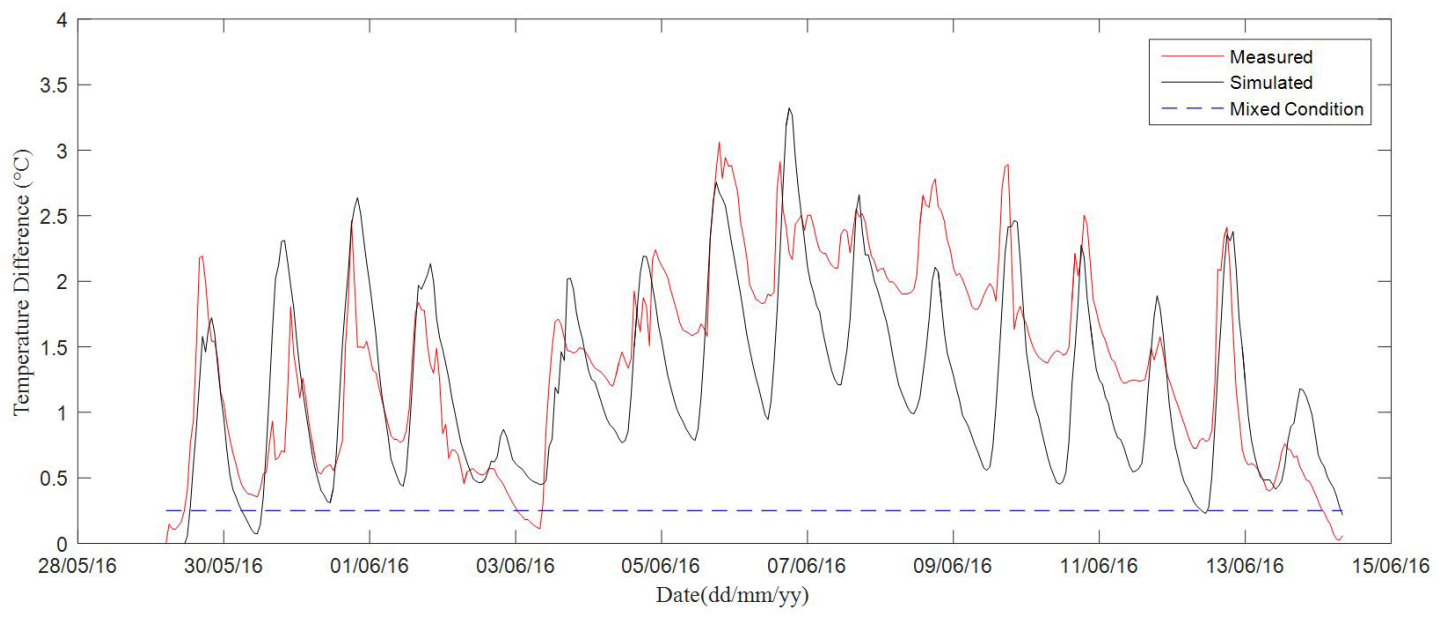

Figure 16. Difference of surface $(0.5 \mathrm{~m})$ and bottom $(9.5 \mathrm{~m})$ for measurement and simulated temperatures for the validation period from May $29^{\text {th }}$ to June $14^{\text {th }} 2016$ at P1 station. Blue dashed line represents a mixing threshold with difference between surface and bottom of $0.25^{\circ} \mathrm{C}$. 
warming was observed at $9.5 \mathrm{~m}$ depth at a constant rate of $0.08^{\circ} \mathrm{C}$ per day. At $2.5 \mathrm{~m}$ depth, the temperature remained constant until $7^{\text {th }}$ June when it began to increase. This temperature dynamics could also be represented by the simulation (Figure 17).

\section{Validation Period in 2015}

A longer period of 88 days (from May $15^{\text {th }}$ to August $10^{\text {th }}$ 2015) was run with the calibrated parameters. For this period, only surface temperature data are available. The simulation results and data measurements during the period are presented in Figure 18. Even with a slightly warmer simulated water temperature, the MAE between the measured and simulated values was very good $\left(0.45^{\circ} \mathrm{C}\right)$, the RMSE $\left(0.65^{\circ} \mathrm{C}\right)$, the RE $(2.08 \%)$ and the $\mathrm{R}^{2}(0.55)$ also presented good values.

\section{Impact of the river inflow}

On June $3^{\text {rd }} 2016$, during the validation period, the water temperature strongly decreased by $1.8^{\circ} \mathrm{C}$ over 4 hours at $9.5 \mathrm{~m}$ and by $0.8^{\circ} \mathrm{C}$ over 12 hours at $5.5 \mathrm{~m}$ (Figure 15 and Figure 17) at station $\mathrm{P} 1$. This strong temperature variation observed only in the deepest layers was not expected. The model was used as a tool to investigate what could be the reason for this cooling observed only below $5.5 \mathrm{~m}$ depth and more intense at $9.5 \mathrm{~m}$ depth. According to the computed water inflow temperature (Figure 19), the tributary water, just before the water cooling, presented a lower temperature $\left(16.1^{\circ} \mathrm{C}\right)$ and, therefore, a higher density, compared to the lake temperature (uniform at $22{ }^{\circ} \mathrm{C}$ ). This colder inflow entered the reservoir during 15 hours (Figure 5), with a high discharge of $50 \mathrm{~m}^{3} / \mathrm{s}$ of the streams Ressaca and Sarandi. On $1^{\text {st }}$ June at $17 \mathrm{~h}$ and $2^{\text {nd }}$ June at $10 \mathrm{~h}$ other inflow high discharge events were observed, however with lower discharge $\left(25.0 \mathrm{~m}^{3} / \mathrm{s}\right.$ of Ressaca and Sarandi streams) and smaller duration (one to two hours). The inflow water temperature, respectively for June $1^{\text {st }}$ and $2^{\text {nd }}$ was $22.0^{\circ} \mathrm{C}$ and $16.2^{\circ} \mathrm{C}$. Even though these events were secondary, compared to the event of June $3^{\text {rd }}$, they occurred in different condition of the water column stratification. On June $1^{\text {st }}$, the lake was stratified, with water surface at $23.9^{\circ} \mathrm{C}$ and bottom at $21.9^{\circ} \mathrm{C}$. On June $2^{\text {nd }}$ the difference of water surface and bottom was less than $0.50{ }^{\circ} \mathrm{C}$, with water surface at $22.3^{\circ} \mathrm{C}$ and bottom at $21.85^{\circ} \mathrm{C}$, therefore, the lake was warmer that the water inflow.

During the peaks of water inflow on June $1^{\text {st }}$ and $2^{\text {nd }}$, no decrease of temperature was measured and simulated at station P1, probably due to a lower inflow discharge and duration that was dissipated before reaching point P1. At the upstream very shallow region, on June $1^{\text {st }}$, no water temperature decrease was observed. However, the water inflow on $2^{\text {nd }}$ June resulted in a water temperature decrease of $1.7^{\circ} \mathrm{C}$ at $2.0 \mathrm{~m}$ depth (reaching 17.6 ${ }^{\circ} \mathrm{C}$ ), $1.6^{\circ} \mathrm{C}$ at $1.1 \mathrm{~m}$ depth (reaching $19.0^{\circ} \mathrm{C}$ ) and $0.6{ }^{\circ} \mathrm{C}$ at $0.5 \mathrm{~m}$ depth (reaching $20.7^{\circ} \mathrm{C}$ ). Figure 20 shows the water temperature profiles at a point in the shallow region indicated in Figure 21 as UP point. Even being lower, the event on June $2^{\text {nd }}$ impacted the bottom temperature that remained colder until a higher inflow arrived on June $3^{\text {rd }}$, in which water temperature reached $16{ }^{\circ} \mathrm{C}$ at this point. This water temperature dynamics, during June $1^{\text {st }}$ and $2^{\text {nd }}$, shows that the first water high inflow was dissipated fast and the second one impacted a wider region of the shallow part of the lake. The colder water remained in the shallow region until the high discharge arrived on June $3^{\text {rd }}$. In the supplementary material videos show the lake temperature at surface (Video 01) and bottom (Video 02) layers of the lake during the validation period. Videos also show the impact of the Tijuco and Mergulhão tributaries (Figure 2) that were not so intense due to a lower inflow rate (Figure 5).

Even with higher inflow, the simulated water level variations at station P1 were less than $12 \mathrm{~cm}$ during the passage of the higher inflow values (Figure 22). This small water variation is in agreement with the downstream condition, in which a water elevation of $0.5 \mathrm{~m}$ would spill $121 \mathrm{~m}^{3} / \mathrm{s}$, much higher that $50 \mathrm{~m}^{3} / \mathrm{s}$, the maximum inflow discharge during the simulated period.

On June $3^{\text {rd }} 2016$ at 13:00 hours, when the water velocity module in the bottom layer at P1 station is maximum, a

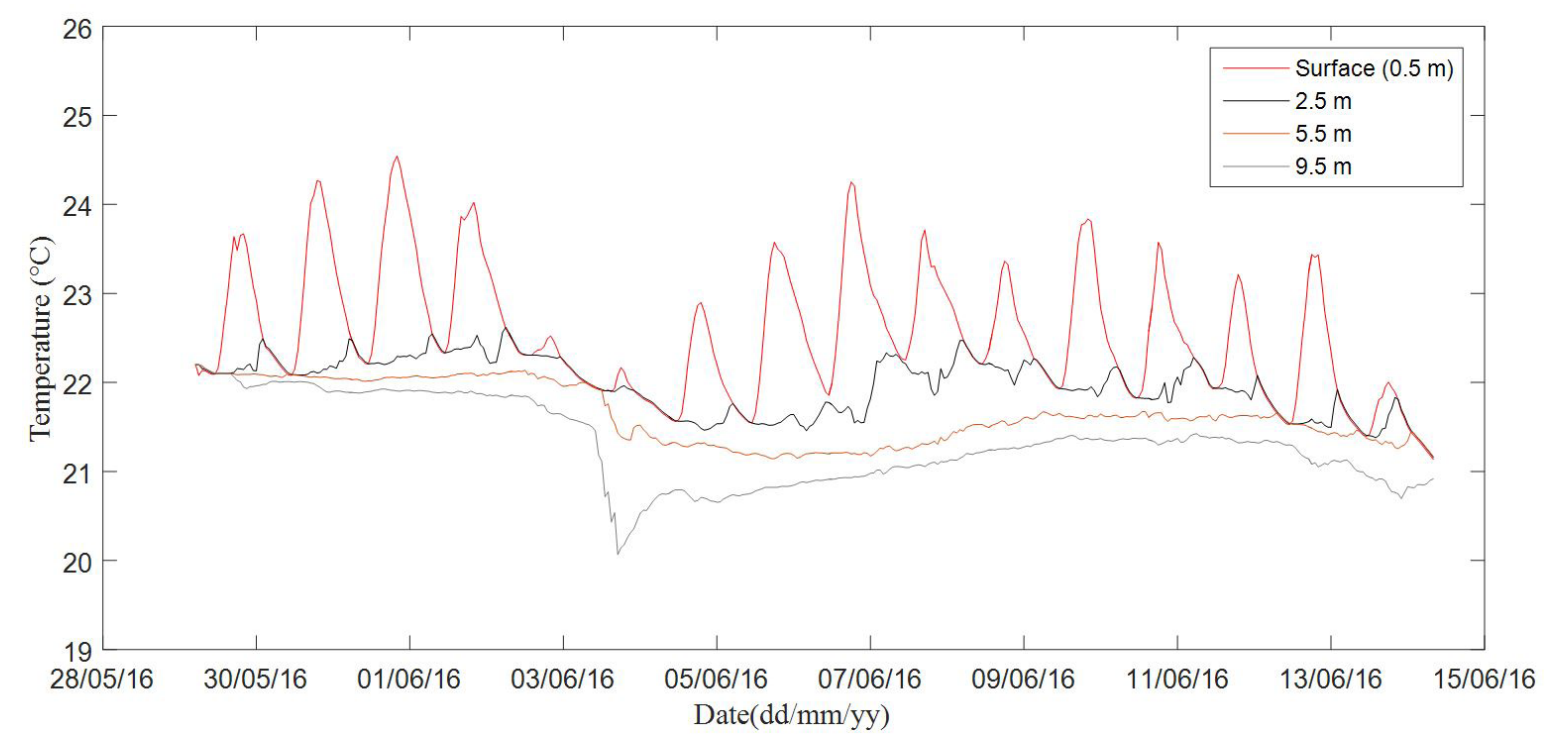

Figure 17. Simulated temperature for the validation period (May $29^{\text {th }}$ to June $14^{\text {th }} 2016$ ) at surface $(0.5 \mathrm{~m}), 2.5 \mathrm{~m}, 5.5 \mathrm{~m}$ and $9.5 \mathrm{~m}$ depths. 

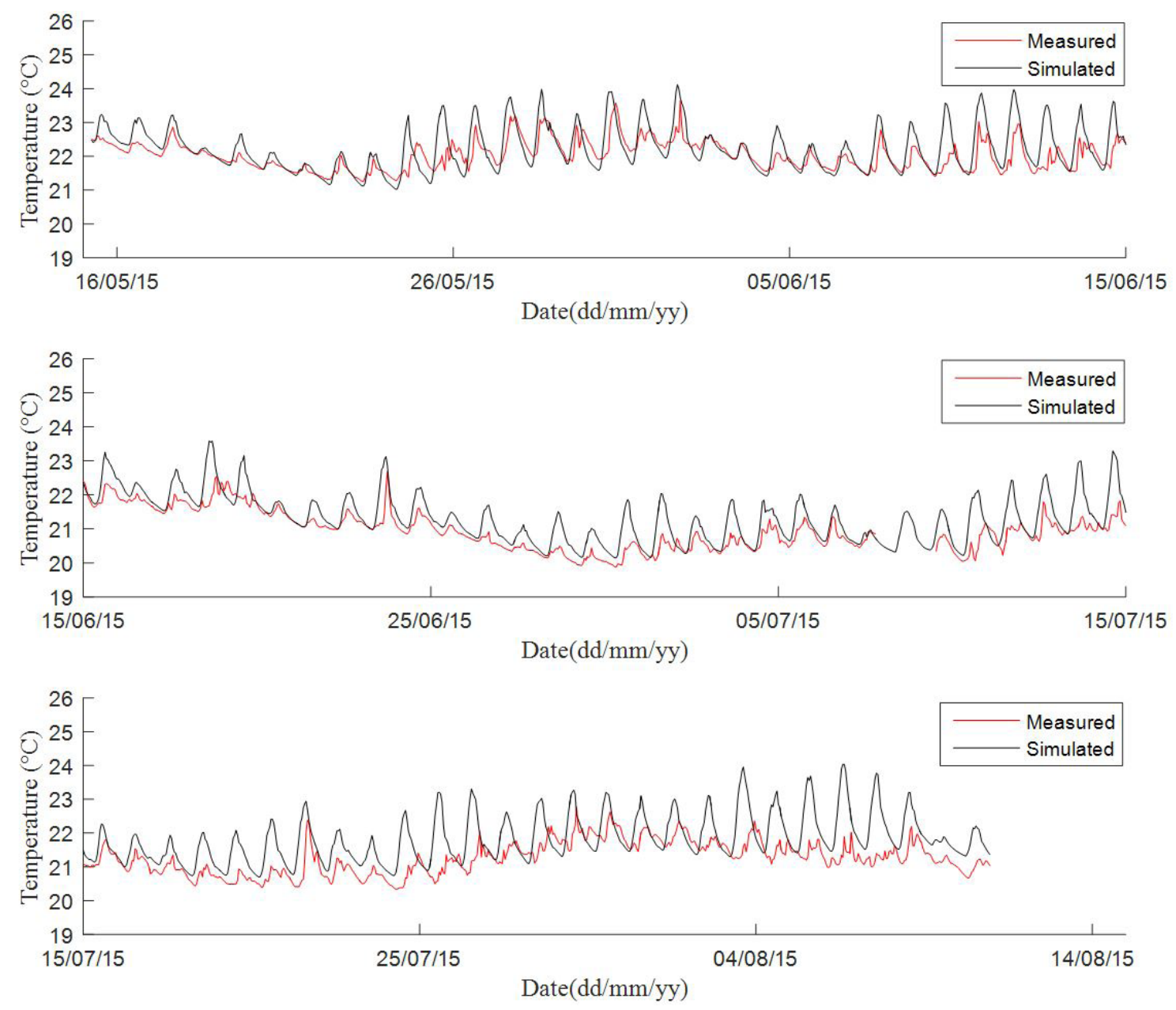

Figure 18 - Measured and simulated temperature at $\mathbf{P}_{\mathbf{1}}$ station at surface $(\mathbf{0 . 5} \mathrm{m})$ depth from May $15^{\text {th }}$ to August $10^{\text {th }} 2015$.

longitudinal transect (Figure 21) of the simulated water temperature shows colder temperature in the lake deeper layers (Figure 23). The model suggests that the propagation of the inflow water on $3^{\text {rd }}$ June occurred through the bottom of the lake (Figure 23 and Figure 24). The inflow water sank to the deepest layers of the lake. The plunging point is located $1500 \mathrm{~m}$ far from the inflow channel, where the lake shallow region ends. In the supplementary material a video shows the lake temperature evolution along the longitudinal transect (Video 03). Unfortunately, the stream inflow water temperature was not measured in this period to confirm this hypothesis. Therefore, to evaluate the influence of the inflow water temperature and to assess the impact of different intensity of inflow water conditions, two simulations considering the water inflow at a constant temperature of $22^{\circ} \mathrm{C}$ were performed for two different scenarios (Figure 19). In the first scenario (D1), the water inflow temperature was considered constant $\left(22^{\circ}\right)$ on June $3^{\text {rd }}$. In the second scenario (D2), the water inflow temperature was considered constant $\left(22^{\circ}\right)$ on June $2^{\text {nd }}$ to $3^{\text {rd }}$. In these simulations the main difference in the temperature profile was on the bottom of the lake (Figure 24) and more evident in the scenario considering the water inflow at a constant temperature during two days (D2). In the simulations with the computed water inflow temperature (validation period) the lake bottom temperature presented a decrease of $1.8^{\circ} \mathrm{C}$ at station $\mathrm{P} 1$.

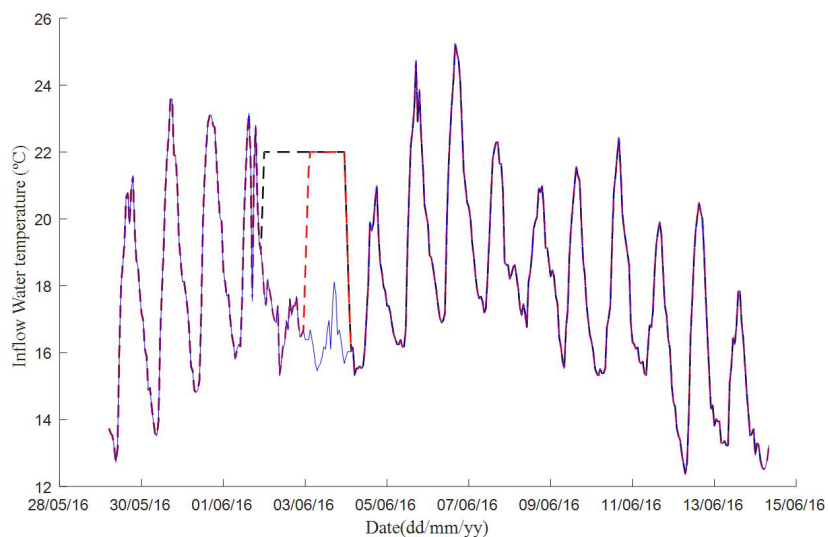

Figure 19. Computed inflow water temperature used as an input during the validation period (May 29 th to June $14^{\text {th }}$ 2016). Red dash line represents the sensitivity analysis with an inflow water temperature with a constant temperature during June $03^{\text {rd }}$ (scenario D1) and the black dash line during June $02^{\text {nd }}$ to $03^{\text {rd }}$ (scenario D2).

In scenario D1, with the inflow water temperature of $22.0^{\circ} \mathrm{C}$, the decrease was $0.8^{\circ} \mathrm{C}$. Changing the inflow water temperature to $20.0^{\circ} \mathrm{C}$, during $3^{\text {rd }}$ June, the decrease was $1.4^{\circ} \mathrm{C}$, and, changing it to $18.0^{\circ} \mathrm{C}$ the decrease was the same of the validated simulation $\left(1.8^{\circ} \mathrm{C}\right)$. Therefore, the variation of the inflow water temperature 


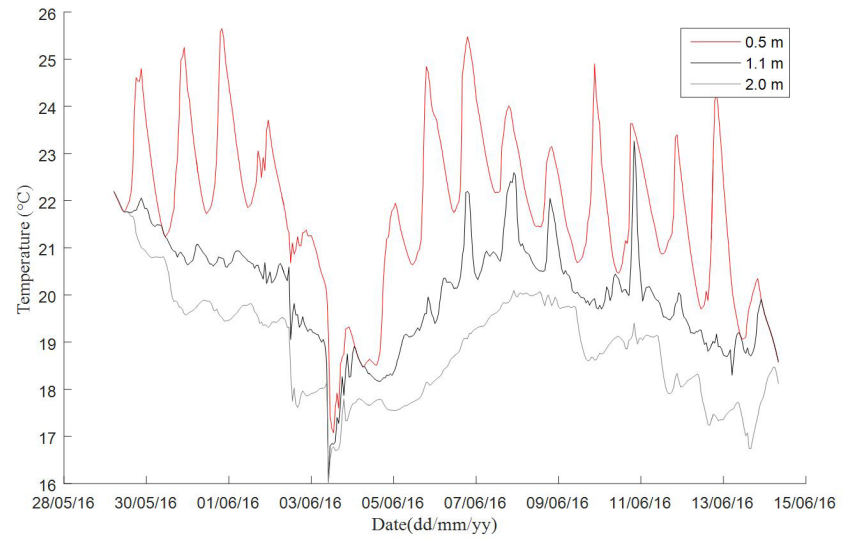

Figure 20. Simulated temperature for the validation period (May 29 $9^{\text {th }}$ to June $\left.14^{\text {th }} 2016\right)$ at surface $(0.5 \mathrm{~m}), 2.5 \mathrm{~m}, 5.5 \mathrm{~m}$ and $9.5 \mathrm{~m}$ depths at the upstream region of the lake (UP point, see Figure 21).

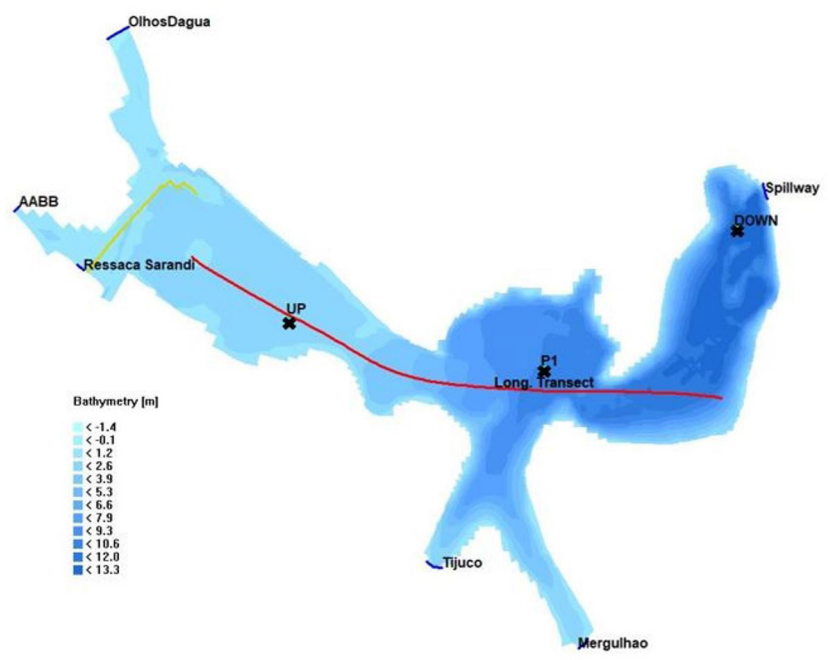

Figure 21. Longitudinal transect of the lake model in red and observation points in black cross.

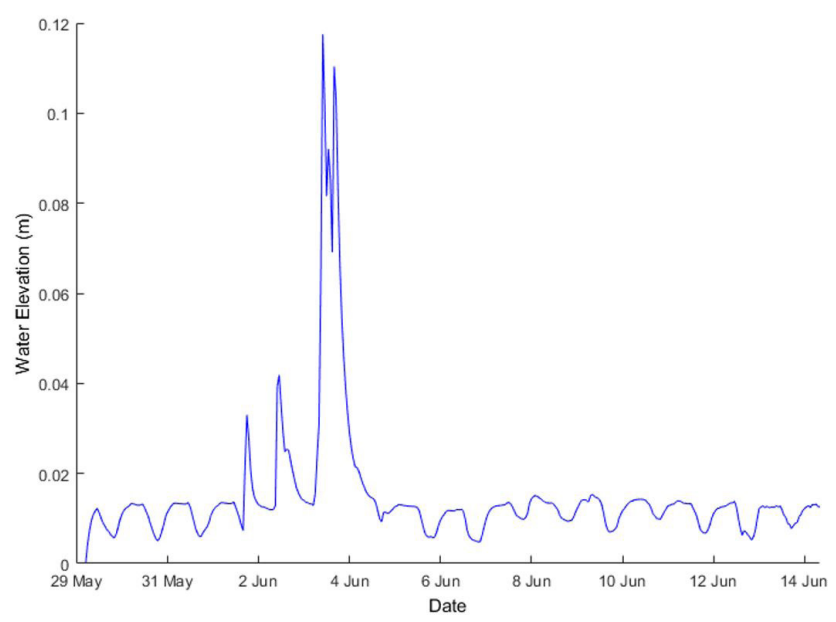

Figure 22. Water level variation during the validation period (May 29 ${ }^{\text {th }}$ to June $14^{\text {th }} 2016$ )

directly impacts the water stratification. For the scenario D2, with the inflow water temperature of $22.0^{\circ} \mathrm{C}$, the decrease of the lake bottom temperature was only $0.2^{\circ} \mathrm{C}$. The difference of water temperature decreases between scenario D1 and D2, with the inflow water temperature of $22.0^{\circ} \mathrm{C}$, shows that the event of $2^{\text {nd }}$ June also influences the water temperature at station P1, even if indirectly. This probably happened because the shallow region of the lake remained at a lower temperature until the inflow peak arrives on $3^{\text {rd }}$ June. Concerning the time evolution of the water velocity module, as expected, the higher values occurred on $3^{\text {rd }}$ June, and due to the water sank to the deeper layers of the lake the higher values were at the bottom. At the moment of higher decrease of the water temperature, the bottom velocity module was $7 \mathrm{~cm} / \mathrm{s}$ and the surface velocity was $1.5 \mathrm{~cm} / \mathrm{s}$. In the scenario $\mathrm{D} 1$, the bottom velocity module was $5.8 \mathrm{~cm} / \mathrm{s}$ and the surface velocity $1 \mathrm{~cm} / \mathrm{s}$. Changing the inflow water temperature to $20^{\circ} \mathrm{C}$ and $18{ }^{\circ} \mathrm{C}$ the water velocity module presented a very slight increase in almost all depths with a higher increase at $9.5 \mathrm{~m}$ depth (Table 11). In the scenario D2, the bottom velocity was $4.5 \mathrm{~cm} / \mathrm{s}$ and the surface velocity $0.5 \mathrm{~cm} / \mathrm{s}$. Table 11 presents the water velocity module in different depths for the presented scenarios.

Close to the spillway, according to the model results, the lake presented a water temperature decrease with a higher intensity at the bottom (Figure 25). This water cooling happened 6 hours later that the cooling observed at station P1 and with a lower intensity (decrease of $1.1^{\circ} \mathrm{C}$ ). Analysing the profile of the water velocity module, the highest value was at bottom $(6.1 \mathrm{~cm} / \mathrm{s})$. The simulated surface velocity module was $2.5 \mathrm{~cm} / \mathrm{s}$. This point (DOWN in Figure 21) is located about $3.0 \mathrm{~km}$ far from the Ressaca and Sarandi inflow channel. Figure 26 and Figure 27 present the profiles of the water velocity module for the UP and DOWN points (Figure 21). According to the simulation values, the dynamics of the upstream region of the lake is different of the downstream region. At the upstream region the lake presents higher velocity module values at surface. At the downstream region the bottom layers present higher velocity values. In the supplementary material videos show the lake velocity module at surface (Video 04) and bottom (Video 05).

Schmidt Stability represents the resistance to mechanical mixing (Idso, 1973). It corresponds to the energy required to completely mix a stratified lake. For the validation period, Schmidt stability shows a pattern of day-night oscillations (Figure 28), induced by the heating and cooling alternation period. It corresponds to the same pattern of the water temperature difference between surface and bottom depths (Figure 16). However, just before of the cooling of the bottom depth on June $3^{\text {rd }}$ (Figure 4 and Figure 17) a mixing of the water column occurs that strongly reduces the value of Schmidt Stability index. This mixing event reduced the daily variation on June $3^{\text {rd }}$, which shows a smaller amplitude. Before the

Table 11. Water velocity module $(\mathrm{cm} / \mathrm{s})$ at station P1 durring the passage of $3^{\text {rd }}$ June peak flow.

\begin{tabular}{cccc}
\hline \multirow{2}{*}{ Depth (m) } & \multicolumn{3}{c}{ Scenario } \\
\cline { 2 - 4 } & $\begin{array}{c}\text { Validation } \\
\text { period }(\mathrm{cm} / \mathrm{s})\end{array}$ & D1 (cm/s) & D2 (cm/s) \\
\hline 0.50 & 1.5 & $1.0^{*} / 1.1^{* *} / 1.3^{* * *}$ & 0.50 \\
2.50 & 1.4 & $0.9^{*} / 1.1^{* *} / 1.2^{* * *}$ & 0.50 \\
5.50 & 1.4 & $1.4^{*} / 1.3^{* *} / 1.3^{* * *}$ & 0.50 \\
9.50 & 7.0 & $5.8^{*} / 6.1^{* *} / 6.2^{* * *}$ & 4.5 \\
\hline
\end{tabular}

Inflow water temperature: $* 22^{\circ} \mathrm{C} * 20^{\circ} \mathrm{C}, * * * 18{ }^{\circ} \mathrm{C}$. 


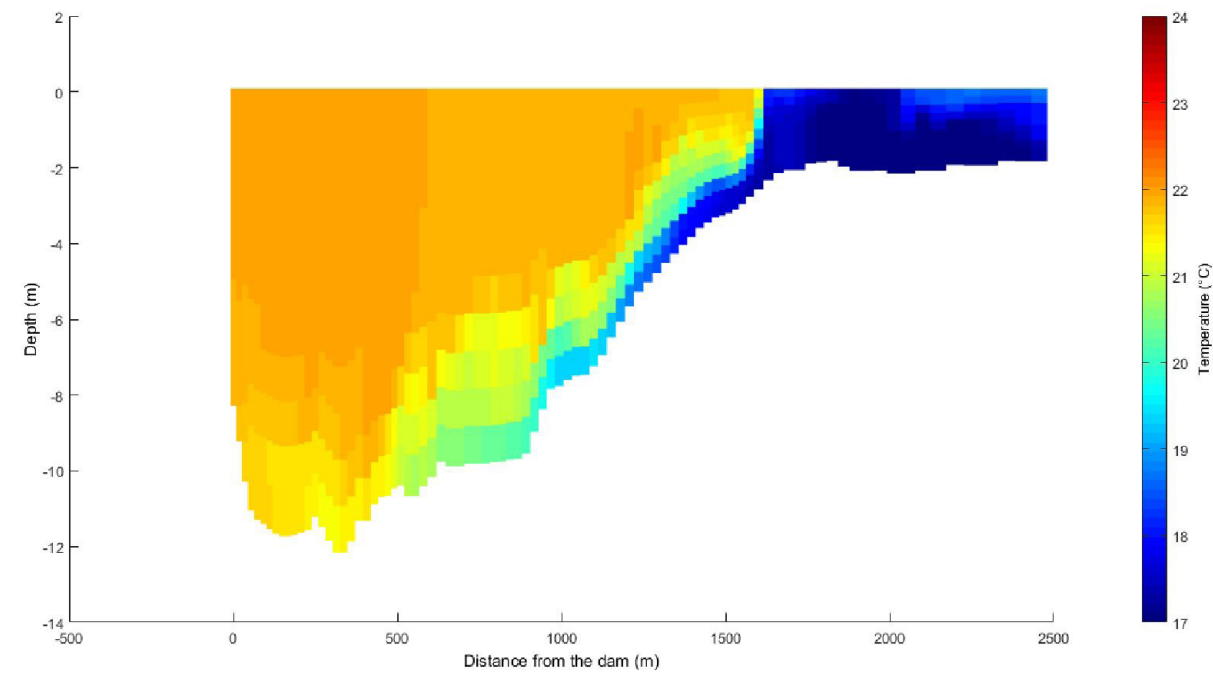

Figure 23. Simulated lake water temperature during high inflow on June $03^{\text {rd }} 2016$ at $13 \mathrm{~h}$ along the reservoir longitudinal transect
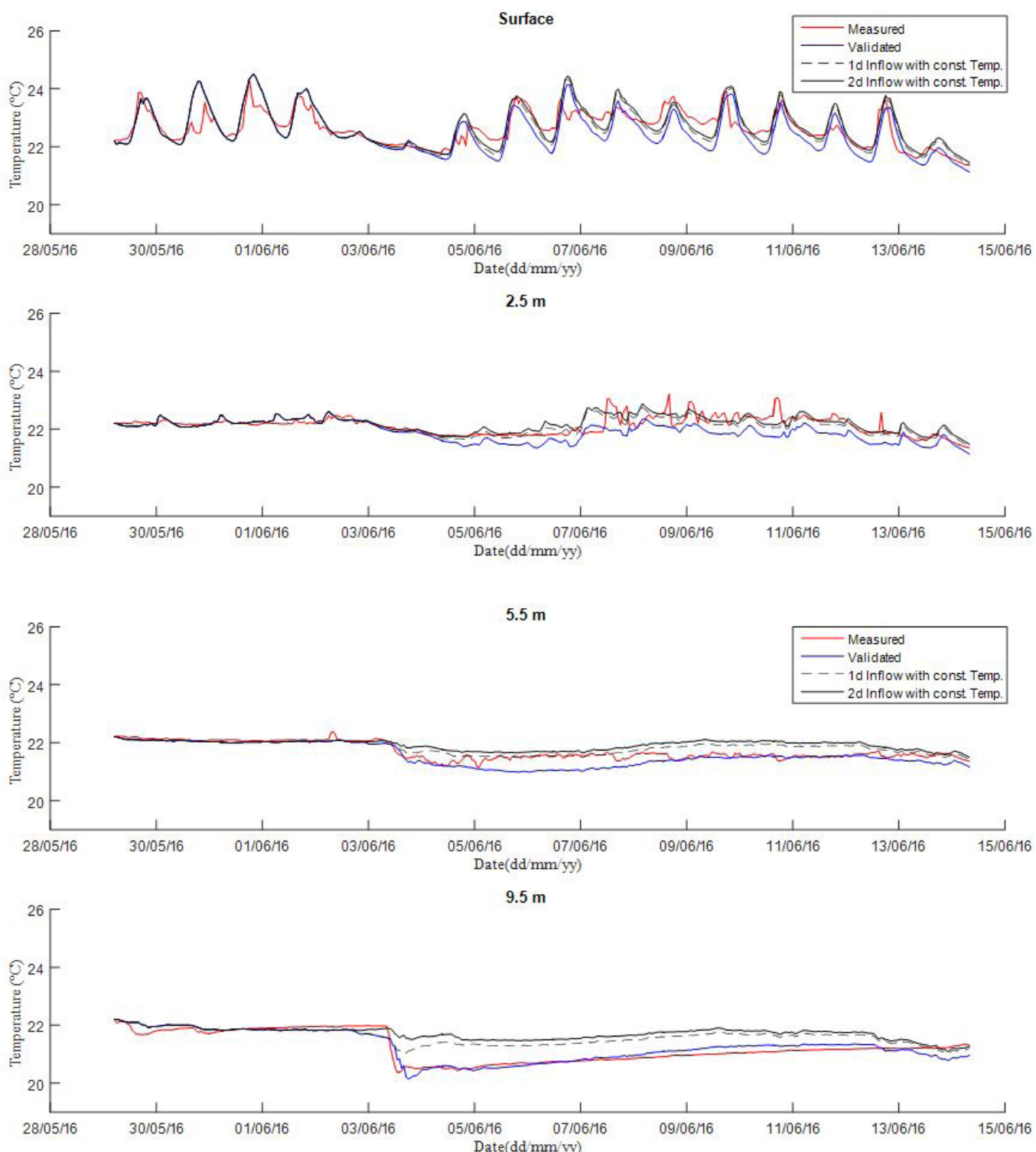

Figure 24. Measured and simulated temperatures at point P1 at the surface $(0.5 \mathrm{~m}), 2.5 \mathrm{~m}, 5.5 \mathrm{~m}, 9.5 \mathrm{~m}$ depths for the validation period simulated (May $29^{\text {th }}$ to June $14^{\text {th }}$ 2016) for different inflow water temperatures (variating and constant). 


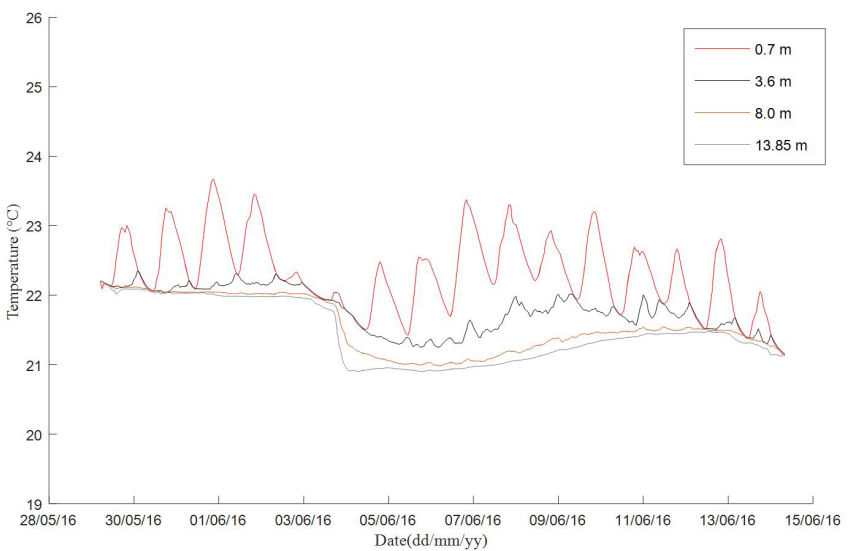

Figure 25. Simulated temperature for the validation period (May 29 $9^{\text {th }}$ to June $\left.14^{\text {th }} 2016\right)$ at surface $(0.5 \mathrm{~m}), 2.5 \mathrm{~m}, 5.5 \mathrm{~m}$ and $9.5 \mathrm{~m}$ depths at the downstream region of the lake (DOWN point in Figure 21). mixing event, the daily variation was around $14 \mathrm{~J} / \mathrm{m}^{2}$, on $3^{\text {rd }}$ June it reduced to $4 \mathrm{~J} / \mathrm{m}^{2}$. Figure 28 also shows that the model could represent this Schmidt stability evolution. However, after June $5^{\text {th }}$, the agreement between measurements and simulated results is weaker (Figure 15), with larger differences between surface and bottom depth (Figure 16), and directly impacting the Schmidt stability index computed from simulated results.

The Lake Number, defined by Imberger \& Patterson (1990), is the ratio of the strength of stratification (Schmidt Stability) to the effect of the wind stress. Lake number below 1 means that the lake stratification is weak with respect to wind stress and the lake will probably mix. According to Figure 28 and Figure 29, the Lake Number peaks were coincident with the Schmidt Stability peaks for measured and simulated values. The high inflow discharge on $3^{\text {rd }}$ and $4^{\text {th }}$ June resulted in the cooling of the bottom of the lake. On $5^{\text {th }}$ June, after the cooling of the bottom depth the water difference between surface and bottom depth increases (Figure 16), which increases the Lake Number to values higher than $600 \mathrm{~J} / \mathrm{m}^{2}$.

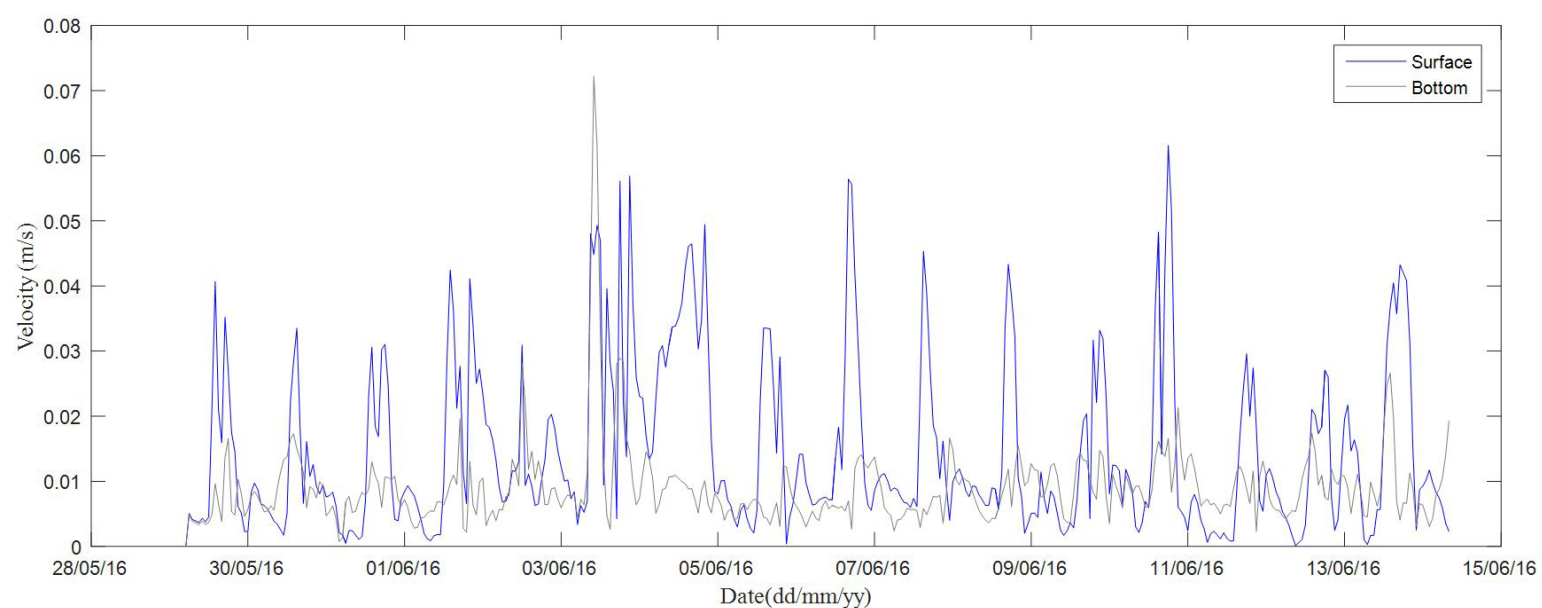

Figure 26. Simulated velocity module at UP point (see Figure 21) for the validation period (May $29^{\text {th }}$ to June $\left.14^{\text {th }} 2016\right)$ at surface $(0.5 \mathrm{~m})$ and bottom $(2.0 \mathrm{~m})$.

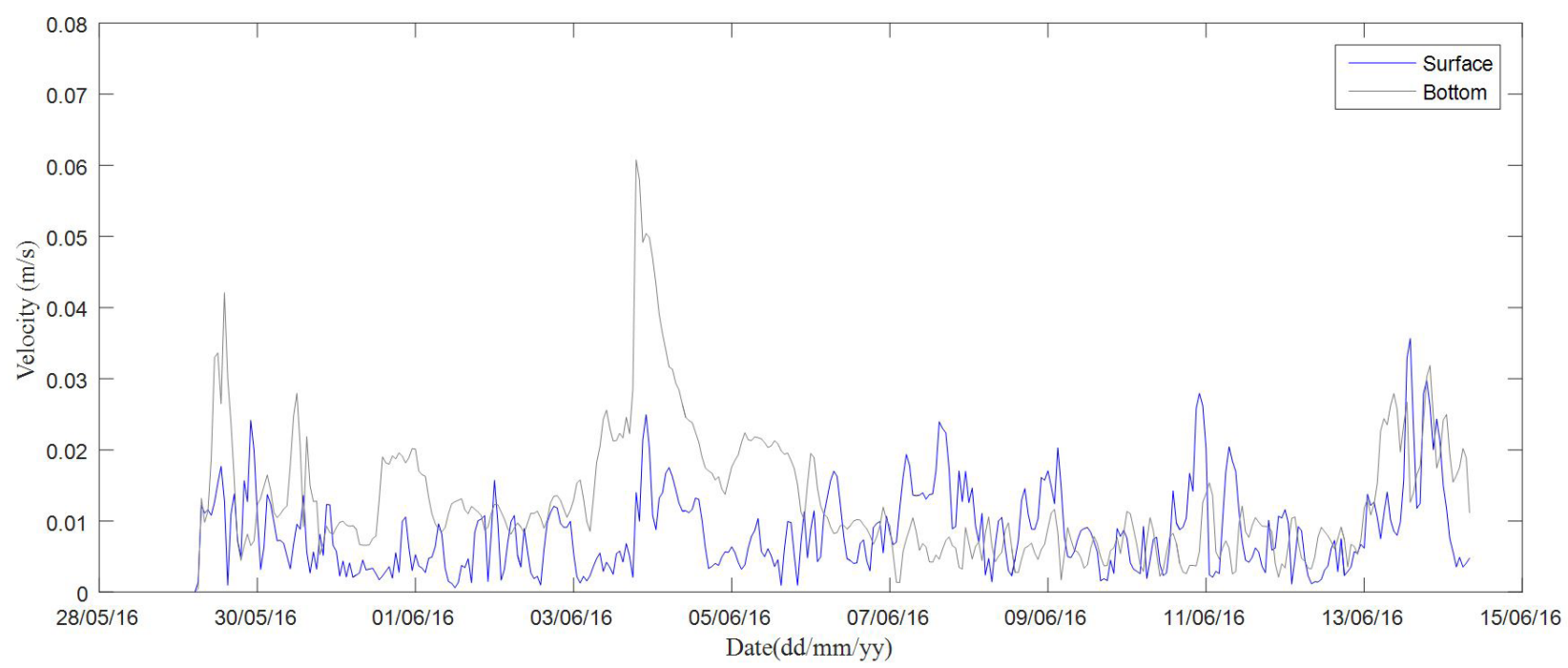

Figure 27. Simulated velocity module at DOWN point (see Figure 21) for the validation period (May $29^{\text {th }}$ to June $14^{\text {th }} 2016$ ) at surface $(0.5 \mathrm{~m})$ and bottom $(13.85 \mathrm{~m})$ 


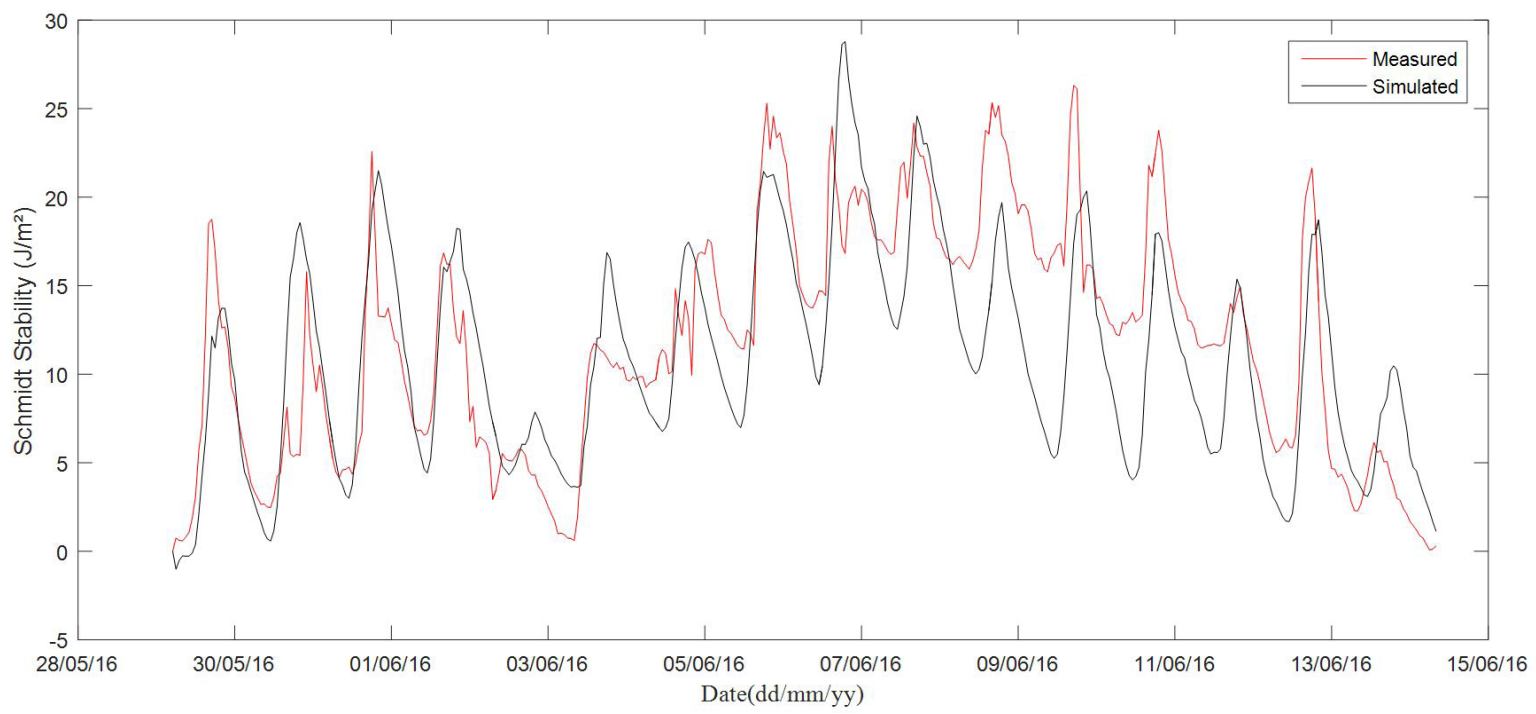

Figure 28. Schmidt stability variation during the validation period (May $29^{\text {th }}$ to June $14^{\text {th }} 2016$ ) at point P1

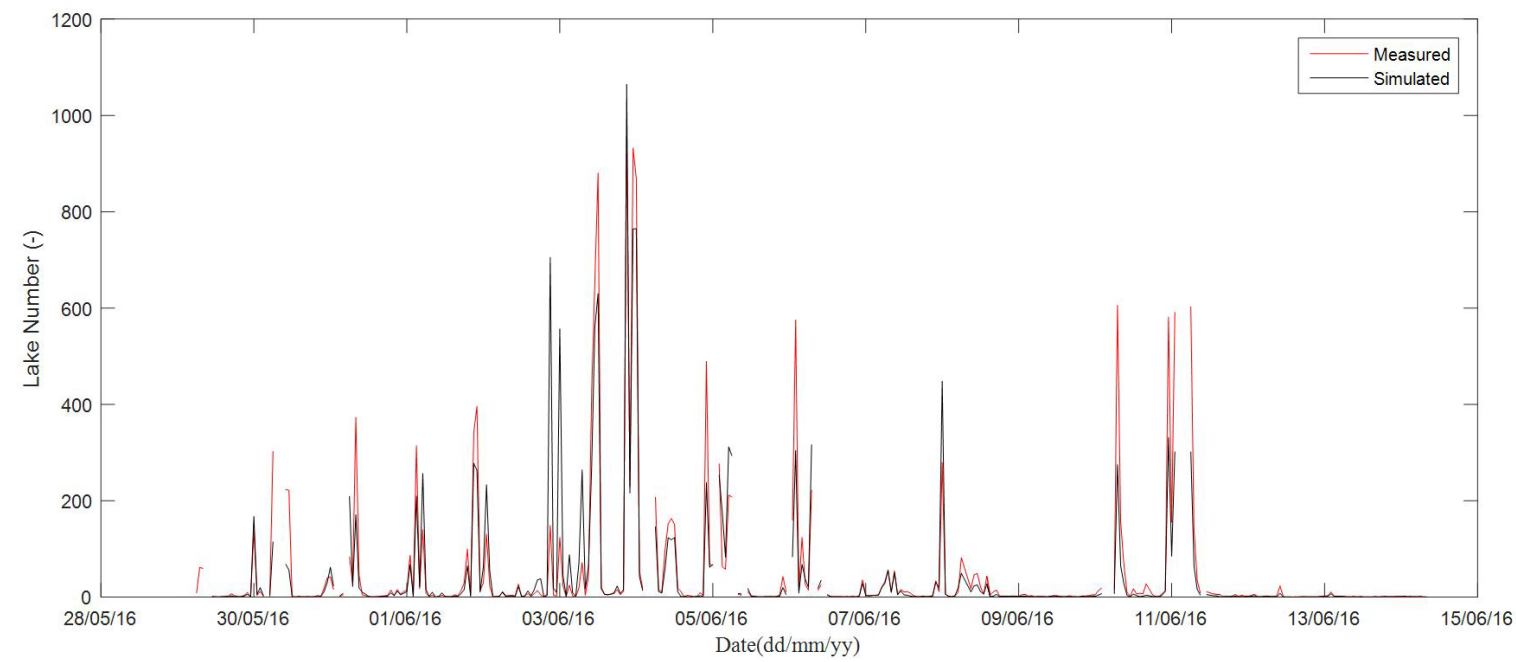

Figure 29. Lake number variation during the validation period (May 29 $9^{\text {th }}$ to June $14^{\text {th }} 2016$ ) at point P1

Thus, the stream inflow impacted the lake stratification strength and the three-dimensional model could represent this pattern.

\section{DISCUSSION}

A literature review of papers published from 2000 to 2015, carried out by Meinson et al. (2016), showed that more than two-thirds of the studies that used high-frequency monitoring in lakes were carried out in northern temperate zone, either in North America or in Europe. The authors, also showed that water temperature was the most common measured parameter, because of the sensor reasonable price and low maintenance and the most important, because water temperature is a controlling factor of biological, ecological and chemical processes (Meinson et al., 2016).

In our paper, a three-dimensional hydrodynamic model, Delft3D-FLOW, was implemented in Lake Pampulha, a shallow urban tropical reservoir. The calibration period lasted 18 days, from May $16^{\text {th }}$ to May $29^{\text {th }} 2016$, corresponding to 440 hourly data at $0.5 \mathrm{~m}, 2.5 \mathrm{~m}, 5.5 \mathrm{~m}$ and $9.5 \mathrm{~m}$ depth. The model could accurately reproduce the alternation of stratification and mixing conditions along the period. The validation period lasted 16 days, from May $29^{\text {th }}$ to June $14^{\text {th }} 2016$, corresponding to 388 hourly data at the same depths of calibration period. Performance indicators showed that the model performed well. The model was also validated for a longer period from May $15^{\text {th }}$ to August $10^{\text {th }} 2015$, corresponding to 2107 hourly data at $0.5 \mathrm{~m}$ depth.

Mean absolute error (MAE) during all simulation periods for water temperature varied between 0.15 and $0.45{ }^{\circ} \mathrm{C}$ and was similar to other three-dimensional model studies. Soulignac et al. (2017) obtained values in a range between 0.25 and $2.34{ }^{\circ} \mathrm{C}$ for Lake Créteil (surface area of $0.4 \mathrm{~km}^{2}$ and mean depth of $4.5 \mathrm{~m}$,) using hourly temperature values at five depths $(0.5,1.5,2.5,3.5$ and $4.5 \mathrm{~m}$ ) over 8 months (around 5500 values). In Lake Yilong (surface area of $28.4 \mathrm{~km}^{2}$ and mean depth of $3.9 \mathrm{~m}$ ), Zhao et al. (2013) obtained a $\mathrm{R}^{2}$ between 0.65 and 0.74 calculated from measured data of 15 campaigns throughout one year, in the same range of our values (0.55 to 0.93). In Lake Minnetonka (maximum depth of $25.0 \mathrm{~m}$ and surface area of $8.01 \mathrm{~km}^{2}$ ), Missaghi \& Hondzo 
(2010) obtained a $\mathrm{R}^{2}$ between 0.91 and 0.98 using 6 months of bi-weekly measured profiles of temperature for calibration and validation period.

Belico (2017) investigated the thermal regime of Lake Pampulha during rain events from 2011 to 2015 with a onedimensional model using hourly measurements of water temperature at surface and monthly vertical profiles. The unidimensional modelling provided a Root Mean Square Error (RMSE) of $1.08^{\circ} \mathrm{C}$ at surface. The authors highlighted that the model could not rightly simulated the lake bottom layers. Other studies were also applied to Lake Pampulha (Silva, 2014; Silva et al., 2016, 2019) however, none of them used three-dimensional modelling with high-frequency measurement in different depths.

In the present paper, high-frequency measurement could detect sudden changes of water temperature with different amplitudes depending on the depth.

The water temperature measurements in the centre of the lake were performed at surface $(0.5 \mathrm{~m}), 2.5 \mathrm{~m}, 5.5 \mathrm{~m}$ and bottom $(9.5 \mathrm{~m})$ and were compared to three-dimensional hydrodynamic model results, allowing a thorough analysis of the lake hydrodynamics. In our paper, the RMSE varied between 0.15 and $0.65^{\circ} \mathrm{C}$ and highfrequency measurement coupled with three-dimensional model could appropriately represent high vertical temperature gradient.

The good simulation results indicate that the meteorological data, collected at a weather station located $3 \mathrm{~km}$ from the lake (and from $9.5 \mathrm{~km}$ for the cloud cover data) reproduce well the meteorological conditions over the lake most of the time. However, the performance of the model may have been affected due to high sensibility of the lake hydrodynamics to external forcing such as nebulosity and wind intensity and direction. Another source of uncertainties was the inflow water temperature that was estimated using air temperature.

Using high-frequency time series, a good model performance was obtained using short simulation period, which is suitable in terms of computation time demand. However, the simulations were not performed for all seasons. We focused on the dry season because it is the period with higher episodes of cyanobacteria blooms. The model must be validated over longer periods representing other hydro-meteorological conditions.

Despite using data from only one monitoring station to calibrate the model and despite the limitation in water inflow temperatures measurements, the model was useful to understand and evaluate the impact of forcing scenarios. During high discharge events, when the river temperature is colder than the lake water, it flows through the deepest layers of the lake. In the simulated episode, the inflow water sank to the bottom of the lake, $1500 \mathrm{~m}$ far from the inflow channel. The model showed that the colder water underflow in the deepest part of the lake is still visible almost $3.5 \mathrm{~km}$ far from the river entrance. The 3D hydrodynamic model could be further used for investigating in other hydrometeorological conditions the complex spatio-temporal dynamics of Lake Pampulha or similar reservoirs.

Lake Pampulha water quality is severely impaired, with recurring hypoxia in the bottom layers (Friese et al., 2010; von Sperling and Campos, 2011). The water current caused by the inflow, through the deepest layers of the lake, may help to renew and oxygenate the water. It also may impact the lake ecological status by affecting the sediment resuspension and nutrient release. Thus, providing a modelling tool which can help to investigate the physical conditions of hypolimnion aeration is an important outcome of this study.

Due to the importance of water stratification and hydrodynamics on phytoplankton growth, our results may also help to understanding algal blooms. The good results of the hydrodynamic model allow, for the next steps, to study phytoplankton and nutrient dynamics by coupling the water quality module.

\section{CONCLUSION}

In this paper, a three-dimensional hydrodynamic model, Delft3D-FLOW, was implemented in Lake Pampulha, a shallow urban tropical reservoir. For the three simulated periods, the agreement between the modelled and hourly measured temperatures were considered very satisfactory.

This paper highlights the complex hydrodynamics of a shallow reservoir and the importance in monitoring the inflow water temperature and discharge. The model outcomes made it possible to investigate the cause of sudden changes in the water temperature. Future studies may focus on extending the simulation period to include rainy season and obtaining data in other monitoring stations in the lake to provide a further assessment of the $3 \mathrm{D}$ hydrodynamic model performance.

Investigating the inflow impact on the lake hydrodynamics may contribute to assess the efficiency of restoration techniques, supporting the decision-making for water management of urban lakes.

\section{ACKNOWLEDGEMENTS}

This research was embedded with a collaboration between LEESU-ENPC (France) within OSS-Cyano research project supported by ANR (French National Research Agency) and EHRUFMG (Brazil) within MoMa-SE research project, supported by CAPES and ANA (Brazilian National Water Agency) and MAPLU-2 funded by Brazilian research funding agency FINEP with funds from the Brazilian Water Resources Sectorial Fund. The authors are grateful to CAPES and ARF for providing financial resource and for all staff involved. The first author received a doctoral fellowship by Ecole des Ponts ParisTech (France) and by CAPES (Brazil). The $4^{\text {th }}$ author benefits of a CNPq-PQ fellowship.

\section{REFERENCES}

Aparicio Medrano, E., Uittenbogaard, R. E., Dionisio Pires, L. M., van de Wiel, B. J. H., \& Clercx, H. J. H. (2013). Coupling hydrodynamics and buoyancy regulation in Microcystis aeruginosa for its vertical distribution in lakes. Ecological Modelling, 248, 41-56. http://dx.doi.org/10.1016/j.ecolmodel.2012.08.029.

Barçante, B., Nascimento, N. O., Silva, T. F. G., Reis, L. A., \& Giani, A. (2020). Cyanobacteria dynamics and phytoplankton species richness as a measure of waterbody recovery: response to phosphorus removal treatment in a tropical eutrophic reservoir. 
Ecological Indicators, 117, 106702. http://dx.doi.org/10.1016/j. ecolind.2020.106702.

Belico, J.C.B. (2017). Impactos de eventos chuvosos na dinâmica físicoquímica e biológica em reservatórios urbanos estudo de caso: Lagoa da Pampulha (Dissertação de mestrado). Universidade Federal de Minas Gerais. Belo Horizonte.

Bennett, N. D., Croke, B. F. W., Guariso, G., Guillaume, J. H. A., Hamilton, S. H., Jakeman, A. J., Marsili-Libelli, S., Newham, L. T. H., Norton, J. P., Perrin, C., Pierce, S. A., Robson, B., Seppelt, R., Voinov, A. A., Fath, B. D., \& Andreassian, V. (2013). Characterising performance of environmental models. Environmental Modelling \& Software, 40,1-20. http://dx.doi.org/10.1016/j.envsoft.2012.09.011.

Birch, S., \& McCaskie, J. (1999). Shallow urban lakes: a challenge for lake management. Hydrobiology, 395-396, 365-378. http:// dx.doi.org/10.1023/A:1017099030774.

Boegman, L., Imberger, J., Ivey, G. N., \& Antenucci, J. P. (2003). High-frequency internal waves in large stratified lakes. Limnology and Oceanography, 48(2), 895-919. http://dx.doi.org/10.4319/ lo.2003.48.2.0895.

Campos, R.G.D. (2004). Estudos Hidrológicos das Bacias do ribeirão Pampulha e do Córrego Cachoeirinha. Belo Horizonte: Departamento de Engenharia Hidráulica e Recursos Hídricos (UFMG - EHR).

Chanudet, V., Fabre, V., \& van der Kaaij, T. (2012). Application of a three-dimensional hydrodynamic model to the Nam Theun 2 Reservoir (Lao PDR). Journal of Great Lakes Research, 38(2), 260269. http://dx.doi.org/10.1016/j.jglr.2012.01.008.

Chen, G., \& Fang, X. (2015). Accuracy of hourly water temperatures in rivers calculated from air temperatures. Water (Basel), 7(12), 1068-1087. http://dx.doi.org/10.3390/w7031068.

Chen, G., \& Fang, X. (2016). Estimating Hourly Water Temperatures in Rivers from Air Temperatures. World Environmental and Water Resources Congress. Reston, VA: American Society of Civil Engineers. http://dx.doi.org/10.1061/9780784479858.017.

Companhia de Pesquisa de Recursos Minerais - CPRM. (2001). Projeto Pampulha - Estudo Hidrogeológico da Bacia da Lagoa da Pampulha. Belo Horizonte: CPRM .

Davidson, K., Anderson, D. M., Mateus, M., Reguera, B., Silke, J., Sourisseau, M., \& Maguire, J. (2016). Forecasting the risk of harmful algal blooms. Harmful Algae, 53, 1-7. PMid:28073436. http://dx.doi.org/10.1016/j.hal.2015.11.005.

Deltares. (2014). Delft3D-FLOW User Manual. Version: 3.15.36498. Netherlands: Deltares.

Prefeitura de Belo Horizonte (2016, Março 18). Prefeitura dá início à recuperação da qualidade da água da lagoa da pampulha. Diário Oficial do Município.
Elliott, J. A. (2012). Is the future blue-green? A review of the current model predictions of how climate change could affect pelagic freshwater cyanobacteria. Water Research, 46(5), 1364-1371. PMid:22244968. http://dx.doi.org/10.1016/j.watres.2011.12.018.

Felisberto, H., Rocha, F., and Palmier, L.R. (2015). Mapeamento da área inundada resultante da propagação de onda de cheia oriunda de ruptura hipotética de barragem - estudo de caso: Barragem da Pampulha. XXI Simpósio Brasileiro de Recursos Hídricos. Brasília: ABRH.

Friese, K., Schmidt, G., de Lena, J. C., Arias Nalini, H., \& Zachmann, D. W. (2010). Anthropogenic influence on the degradation of an urban lake - The Pampulha reservoir in Belo Horizonte, Minas Gerais, Brazil. Limnologica - Ecology and Management of Inland Waters, 40, 114-125.

Gonçalves, A. L., Pires, J. C. M., \& Simões, M. (2016). The effects of light and temperature on microalgal growth and nutrient removal: an experimental and mathematical approach. RSC Advances, 6(27), 22896-22907. http://dx.doi.org/10.1039/C5RA26117A.

Gong, R., Xu, L., Wang, D., Li, H., \& Xu, J. (2016). Water quality modeling for a typical urban lake based on the EFDC model. Environmental Modeling and Assessment, 21(5), 643-655. http:/ /dx.doi. org/10.1007/s10666-016-9519-1.

Grimaud, G. M., Mairet, F., Sciandra, A., \& Bernard, O. (2017). Modeling the temperature effect on the specific growth rate of phytoplankton: a review. Reviews in Environmental Science and Biotechnology, 16(4), 625-645. http://dx.doi.org/10.1007/s11157017-9443-0.

Hébert, C., Caissie, D., Satish, M. G., \& El-Jabi, N. (2015). Predicting hourly stream temperatures using the equilibrium temperature model. Journal of Water Resource and Protection, 07(04), 322-338. http://dx.doi.org/10.4236/jwarp.2015.74026.

Ho, J. C., \& Michalak, A. M. (2015). Challenges in tracking harmful algal blooms: A synthesis of evidence from Lake Erie. J. Gt. Lakes Res., 41(2), 317-325. http://dx.doi.org/10.1016/j.jglr.2015.01.001.

Instituto Brasileiro de Geografia e Estatística - IBGE (2014). Anuário Estatístico do Brasil. Rio de Janeiro: IBGE.

Idso, S. B. (1973). On the concept of lake stability. Limnology and Oceanography, 18(4), 681-683. http://dx.doi.org/10.4319/ lo.1973.18.4.0681.

Imberger, J., \& Patterson, J. C. (1990). Physical limnology. In J.W. Hutchinson \& T.Y. Wu (Eds.), Advances in applied mechanics (pp. 303-475). Elsevier.

Jin, K.-R., Hamrick, J. H., \& Tisdale, T. (2000). Application of three-dimensional hydrodynamic model for lake okeechobee. Journal of Hydraulic Engineering, 126(10), 758-771. http://dx.doi. org/10.1061/(ASCE)0733-9429(2000)126:10(758). 
Thermal functioning of a tropical reservoir assessed through three-dimensional modelling and high-frequency monitoring

Jöhnk, K. D., Huisman, J., Sharples, J., Sommeijer, B., Visser, P. M., \& Stroom, J. M. (2008). Summer heatwaves promote blooms of harmful cyanobacteria. Global Change Biology, 14(3), 495-512. http://dx.doi.org/10.1111/j.1365-2486.2007.01510.x.

Li-Kun, Y., Sen, P., Xin-hua, Z., \& Xia, L. (2017). Development of a two-dimensional eutrophication model in an urban lake (China) and the application of uncertainty analysis. Ecological Modelling, 345, 63-74. http://dx.doi.org/10.1016/j.ecolmodel.2016.11.014.

Matos, A. C. S., Lemos, R. S., Silva, T. F. G., Eleutério, J. C., \& Nascimento, N. (2017). Evolução do uso e ocupação do solo em mananciais de abastecimento metropolitano na região metropolitana de Belo Horizonte, Estado de Minas Gerais. XXII Simpósio Brasileiro de Recursos Hidricos. Florianópolis-SC. Florianópolis: ABRH.

Meinson, P., Idrizaj, A., Noges, P., Noges, T., \& Laas, A. (2016). Continuous and high-frequency measurements in limnology: history, applications, and future challenges. Environmental Reviews, 24(1), 52-63. http://dx.doi.org/10.1139/er-2015-0030.

Missaghi, S., \& Hondzo, M. (2010). Evaluation and application of a three-dimensional water quality model in a shallow lake with complex morphometry. Ecological Modelling, 221(11), 1512-1525. http://dx.doi.org/10.1016/j.ecolmodel.2010.02.006.

Nogueira, M. M. (2015). Elaboração da curva chave dos córregos Ressaca e Sarandi utilizando métodos computacionais (Trabalho de Conclusão de Curso) - Universidade Federal de Minas Gerais, Belo Horizonte.

Phlips, E. J., Badylak, S., \& Grosskopf, T. (2002). Factors affecting the abundance of phytoplankton in a restricted subtropical Lagoon, the Indian River Lagoon, Florida, USA. Estuarine, Coastal and Shelf Science, 55(3), 385-402. http://dx.doi.org/10.1006/ecss.2001.0912.

Prefeitura de Belo Horizonte. (2017). Politica Municipal de Saneamento de Belo Horizonte. PMS.

Qin, B., Li, W., Zhu, G., Zhang, Y., Wu, T., \& Gao, G. (2015). Cyanobacterial bloom management through integrated monitoring and forecasting in large shallow eutrophic Lake Taihu (China). Journal of Hazardous Materials, 287, 356-363. PMid:25679801. http://dx.doi.org/10.1016/j.jhazmat.2015.01.047.

Read, J. S., Hamilton, D. P., Jones, I. D., Muraoka, K., Winslow, L. A., Kroiss, R., Wu, C. H., \& Gaiser, E. (2011). Derivation of lake mixing and stratification indices from high-resolution lake buoy data. Environmental Modelling \& Software, 26(11), 1325-1336. http://dx.doi.org/10.1016/j.envsoft.2011.05.006.

Reynolds, C. S. (1998). What factors influence the species composition of phytoplankton in lakes of different trophic status? Hydrobiologia, 369, 11-26. http://dx.doi.org/10.1023/A:1017062213207.

Scriban, A., Lemaire, B., \& Vinçon-Leite, B. (2015). Configuration d'un modèle de prévision de l'évolution à court terme des dynamiques bydrodynamiques et biogéochimiques dans le plan d'eau urbain de Champs-
sur-Marne. Mémoire de stage de deuxième année. Agro Paris Tech. Paris, France : LEESU.

Silva, T. F. G. (2014). Suivi et modélisation de la dynamique des cyanobactéries dans les lacs urbains au sein de leur bassin versant. Université Paris-Est and Universidade Federal de Minas Gerais.

Silva, T. F., Vinçon-Leite, B., Giani, A., Figueredo, C. C., Petrucci, G., Lemaire, B., Sperling, E. V., Tassin, B., Seidl, M., Khac, V. T., Viana, P. S., Viana, V. F. L., Toscano, R. A., Rodrigues, B. H. M., \& Nascimento, N. O. (2016). Modelagem da Lagoa da Pampulha: uma ferramenta para avaliar o impacto da bacia hidrográfica na dinâmica do fitoplâncton. Engenharia Sanitaria e Ambiental, 21(1), 95-108. http://dx.doi.org/10.1590/S1413-41520201600100125692.

Silva, T. F. G., Vinçon-Leite, B., Lemaire, B. J., Petrucci, G., Giani, A., Figueredo, C. C., \& Nascimento, N. de O. (2019). Impact of urban stormwater runoff on cyanobacteria dynamics in a tropical urban lake. Water (Basel), 11(5), 946. http://dx.doi.org/10.3390/ w11050946.

Simpson, J. H., Lucas, N. S., Powell, B., \& Maberly, S. C. (2015). Dissipation and mixing during the onset of stratification in a temperate lake, Windermere. Limnology and Oceanography, 60(1), 29-41. http://dx.doi.org/10.1002/lno.10008.

Siqueira, R. C., Moura, P. M., \& Silva, T. F. (2019). Methodology for the construction of an urban flood hazard chart. RBRH, 24, 24. http://dx.doi.org/10.1590/2318-0331.241920180125.

Soulignac, F., Vinçon-Leite, B., Lemaire, B. J., Scarati, R., Bonhomme, C., Dubois, P., Mezemate, Y., Tchiguirinskaia, I., Schertzer, D., \& Tassin, B. (2017). Performance assessment of a 3D hydrodynamic model using high temporal resolution measurements in a shallow urban lake. Environmental Modeling and Assessment, 22(4), 309-322. http://dx.doi.org/10.1007/s10666-017-9548-4.

Soulignac, F., Danis, P.-A., Bouffard, D., Chanudet, V., Dambrine, E., Guénand, Y., Harmel, T., Ibelings, B.W., Trevisan, D., Uittenbogaard, R., \& Anneville, O. (2018). Using 3D modeling and remote sensing capabilities for a better understanding of spatio-temporal heterogeneities of phytoplankton abundance in large lakes. Journal of Great Lakes Research, 44(4), 756-764.

von Sperling, E., \& Campos, M.O. (2011). Restoration of Lake Pampulha, Brazil by using sanitation and in-lake techniques. In Proceedings of the 35 th WEDC International Conference. Loughborough, UK: Loughborough University.

Stefan, H. G., \& Preud'homme, E. B. (1993). Stream Temperature Estimation from Air Temperature1. Journal of the American Water Resources Association, 29(1), 27-45. http://dx.doi. org/10.1111/j.1752-1688.1993.tb01502.x.

UNESCO. (1981). Background papers and supporting data on the practical salinity scale 1978. Paris : Unesco. 
Van Donk, E. (1984). Factors influencing phytoplankton growth and succession in Lake Maarsseveen I. Hydrological Bulletin, 18(1), 69-71. http://dx.doi.org/10.1007/BF02256678.

Vinçon-Leite, B., \& Casenave, C. (2019). Modelling eutrophication in lake ecosystems: A review. The Science of the Total Environment, $651 \mathrm{Pt}$ 2), 2985-3001. http://dx.doi.org/10.1016/j.scitotenv.2018.09.320.

Vinnå, L. R., Wüest, A., \& Bouffard, D. (2017). Physical effects of thermal pollution in lakes. Water Resources Research, 53(5), 39683987. http://dx.doi.org/10.1002/2016WR019686.

Whyte, C., Swan, S., \& Davidson, K. (2014). Changing wind patterns linked to unusually high Dinophysis blooms around the Shetland Islands, Scotland. Harmful Algae, 39, 365-373. http:// dx.doi.org/10.1016/j.hal.2014.09.006.

Wu, T., Qin, B., Zhu, G., Luo, L., Ding, Y., \& Bian, G. (2013). Dynamics of cyanobacterial bloom formation during shortterm hydrodynamic fluctuation in a large shallow, eutrophic, and wind-exposed Lake Taihu, China. Environmental Science and Pollution Research International, 20(12), 8546-8556. http://dx.doi. org/10.1007/s11356-013-1812-9.

Wu, T., Qin, B., Brookes, J. D., Shi, K., Zhu, G., Zhu, M., Yan, W., \& Wang, Z. (2015). The influence of changes in wind patterns on the areal extension of surface cyanobacterial blooms in a large shallow lake in China. The Science of the Total Environment, 518-519, 24-30. http://dx.doi.org/10.1016/j. scitotenv.2015.02.090.

Yi, X., Zou, R., \& Guo, H. (2016). Global sensitivity analysis of a three-dimensional nutrients-algae dynamic model for a large shallow lake. Ecological Modelling, 327, 74-84. http://dx.doi.org/10.1016/j. ecolmodel.2016.01.005.
Zbiciński, I., \& Ziemińska-Stolarska, A. (2017). Analysis of factors affecting the ecological status of the large water bodies on the basis of monitoring and integrated 3D models. E3S Web Conf. 19, 8.

Zhao, L., Li, Y., Zou, R., He, B., Zhu, X., Liu, Y., Wang, J., \& Zhu, Y. (2013). A three-dimensional water quality modeling approach for exploring the eutrophication responses to load reduction scenarios in Lake Yilong (China). Environmental Pollution, 177, 13-21. http:/ / dx.doi.org/10.1016/j.envpol.2013.01.047.

\section{Authors contributions}

Denis Furstenau Plec: Lead the conceptualization, obtained the results and wrote the text.

Talita Fernanda das Graças Silva: Lead the text writing-review and editing and lead the data collection.

Brigitte Vinçon-Leite: Lead the conceptualization, formal analysis, methodology, supervision and validation. Contributed with technical notes and revised the text.

Nilo Nascimento: Lead the project funding, administration and the supervision. Contributed with technical notes and revised the text.

Editor-in-Chief: Adilson Pinheiro.

Associated Editor: Cristóvão Vicente Scapulatempo Fernandes. 